medRxiv preprint doi: https://doi.org/10.1101/19002741; this version posted July 20, 2019. The copyright holder for this preprint (which was not certified by peer review) is the author/funder, who has granted medRxiv a license to display the preprint in perpetuity.

\title{
1 A pooled analysis of the duration of chemoprophylaxis against malaria after treatment with
} 2 artesunate-amodiaquine and artemether-lumefantrine

4 MT Bretscher ${ }^{1 * \dagger} \uparrow$, P Dahal ${ }^{2,3}$, J Griffin $^{4}$, K Stepniewska $^{2,3}$, Q Bassat $^{5,6,7,8,9}$, E Baudin $^{10}, \mathrm{U}$

5 D'Alessandro $^{11}$, AA Djimde ${ }^{12}$, G Dorsey $^{13}$, E Espié $^{10,14}$, B Fofana ${ }^{12}$, R González $^{5,6}$, E Juma $^{15}, \mathrm{C}$

6 Karema $^{16,17}$, E Lasry $^{18}$, B Lell $^{19,20}, \mathrm{~N} \mathrm{Lima}^{21}, \mathrm{C} \mathrm{Menéndez}^{5,6}, \mathrm{G} \mathrm{Mombo-Ngoma}^{20,22,23}$, C Moreira ${ }^{2,3}$, F

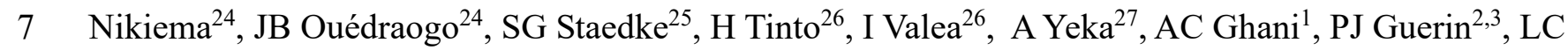

8 Okell $^{1 *}$.

10 1. MRC Centre for Global Infectious Disease Analysis, Department of Infectious Diseases,

11 Imperial College London, London, UK.

12 2. WorldWide Antimalarial Resistance Network (WWARN), Oxford, UK.

13 3. Centre for Tropical Medicine \& Global Health, Nuffield Department of Medicine, University of 14 Oxford, Oxford, UK.

15 4. School of Mathematical Sciences, Queen Mary University of London, London, UK.

16 5. Centro de Investigação em Saúde de Manhiça (CISM), Maputo, Mozambique.

17 6. ISGlobal, Hospital Clínic - Universitat de Barcelona, Barcelona, Spain.

187 ICREA, Pg. Lluís Companys 23, 08010 Barcelona, Spain.

19 8. Pediatric Infectious Diseases Unit, Pediatrics Department, Hospital Sant Joan de Déu

20 (University of Barcelona), Barcelona, Spain.

21 9. Consorcio de Investigación Biomédica en Red de Epidemiología y Salud Pública (CIBERESP),

22 Madrid, Spain.

23 10. Epicentre, Paris, France.

24 11. MRC Unit The Gambia at the London School of Hygiene and Tropical Medicine, Fajara, The 25 Gambia

26 12. Malaria Research and Training Center, University of Science, Techniques and Technologies of 27 Bamako, Bamako, Mali.

28 13. Department of Medicine, University of California San Francisco, San Francisco, USA.

29 14. GSK Vaccines, R\&D Center, Clinical and Epidemiology Department, Wavre, Belgium.

30 15. Centre for Global Health Research, Kenya Medical Research Institute, Kisumu, Kenya.

31 16. Swiss Tropical and Public Health Institute, Basel, Switzerland. 
medRxiv preprint doi: https://doi.org/10.1101/19002741; this version posted July 20, 2019. The copyright holder for this preprint (which was not certified by peer review) is the author/funder, who has granted medRxiv a license to display the preprint in perpetuity.

32 17. University of Basel, Basel, Switzerland.

33 18. Medecins Sans Frontieres-OCBA, Barcelona, Spain.

34 19. Department of Medicine I, Division of Infectious Diseases and Tropical Medicine, Medical

35 University of Vienna, Vienna, Austria.

36 20. Centre de Recherches Medicales de Lambarene, Lambarene, Gabon.

37 21. Department of Paediatrics, University of Calabar, Calabar, Nigeria.

38 22. Institute for Tropical Medicine, University of Tubingen, Tubingen, Germany.

39 23. Department of Tropical Medicine, Bernhard Nocht Institute for Tropical Medicine \& I.

40 Department of Medicine, University Medical Center Hamburg-Eppendorf, Hamburg, Germany.

$4124 . \quad$ Institut de Recherche en Science de la Sante, Bobo-Dioulasso, Burkina Faso.

42 25. Department of Clinical Research, Faculty of Infectious \& Tropical Diseases, London School of

43 Hygiene \& Tropical Medicine, London, UK.

44 26. Institut de Recherche en Science de la Sante, Nanoro, Burkina Faso.

45 27. Uganda Malaria Surveillance Project, Kampala, Uganda.

$46 *$ Corresponding authors.

$47 \dagger$ Present Address: F. Hoffmann-La Roche Ltd, Basel, Switzerland. 
medRxiv preprint doi: https://doi.org/10.1101/19002741; this version posted July 20, 2019. The copyright holder for this preprint (which was not certified by peer review) is the author/funder, who has granted medRxiv a license to display the preprint in perpetuity.

\section{Abstract}

51 Artemether-lumefantrine (AL) and artesunate-amodiaquine (AS-AQ) are the most commonly-used

52 treatments against Plasmodium falciparum malaria in Africa. The lumefantrine and amodiaquine

53 partner drugs may provide differing durations of post-treatment prophylaxis, an important additional

54 benefit to patients. Analyzing 4214 individuals from clinical trials in 12 sites, we estimated a mean

55 duration of post-treatment protection of 13.0 days (95\% CI 10.7-15.7) for AL and 15.2 days (95\% CI

56 12.8-18.4) for AS-AQ after allowing for transmission intensity. However, the duration varied

57 substantially between sites: where wild type $p f m d r 186$ and $p f c r t 76$ parasite genotypes predominated,

58 AS-AQ provided $~ 2$-fold longer protection than AL. Conversely, AL provided up to 1.5-fold longer

59 protection than AS-AQ where mutants were common. We estimate that choosing AL or AS-AQ as

60 first-line treatment according to local drug sensitivity could alter population-level clinical incidence of

61 malaria by up to $14 \%$ in under-five year olds where malaria transmission is high.

62

63 
medRxiv preprint doi: https://doi.org/10.1101/19002741; this version posted July 20, 2019. The copyright holder for this preprint (which was not certified by peer review) is the author/funder, who has granted medRxiv a license to display the preprint in perpetuity.

\section{Introduction}

66 Nearly all malaria-endemic countries use artemisinin-based combination therapies (ACTs) as first-line treatment for uncomplicated Plasmodium falciparum malaria. In each ACT, the artemisinin derivative is combined with a different antimalarial partner drug. There are currently five ACTs recommended by the World Health Organization (WHO): artemether-lumefantrine (AL), artesunate-amodiaquine (ASAQ), dihydroartemisinin (DHA)-piperaquine, artesunate-mefloquine (AS-MQ), and artesunatesulfadoxine-pyrimethamine (AS-SP) (1). In areas where other ACTs are failing, WHO also suggest considering a sixth ACT: artesunate-pyronaridine, now prequalified by WHO (2).

Each of the six drug regimens has different pharmacokinetic and pharmacodynamic properties, and these have implications for the public health benefit of the drugs in terms of their ability to reduce overall malaria transmission in the community, as well as cure disease (3). The artemisinin derivatives are highly potent antimalarials that rapidly reduce the parasite biomass; however, they have a very short half-life. The partner drugs remain in the blood for longer, clearing remaining parasites and incidentally providing chemoprophylaxis against reinfection which may have an important impact in moderate-to-high transmission areas (4-6). Some antimalarials have additional activity against

81 gametocytes, the transmissible form of the parasite, and these are better at preventing onward transmission from the patient after treatment. Gametocyte killing may therefore benefit the community through reduction of the overall transmission level (5).

Artemether-lumefantrine (AL) is globally the most widely used ACT, followed by artesunateamodiaquine (AS-AQ) (7). While resistance to artemisinin has emerged in South-East Asia (8) and a degree of resistance to the partner drugs exists in some parts of the world, both treatments remain highly effective in most African malaria-endemic areas (9-12). The pharmacokinetic properties of each drug are relatively well characterized: lumefantrine and its metabolite desbutyl-lumefantrine have terminal elimination half-lives of 1-10 days $(1,13-16)$, while desethylamodiaquine, the active metabolite of amodiaquine, has a half-life of 4-10 days (1, 17-22). However, these estimates do not

92 provide information on the duration of post-treatment prophylaxis which also depends on the

93 pharmacodynamics of the drug. 
medRxiv preprint doi: https://doi.org/10.1101/19002741; this version posted July 20, 2019. The copyright holder for this preprint (which was not certified by peer review) is the author/funder, who has granted medRxiv a license to display the preprint in perpetuity.

95 There is evidence that the duration of protection after AS-AQ and AL treatment is affected by parasite

96 mutations associated with reduced drug sensitivity $(9,11)$. These two drugs show collateral sensitivity,

97 such that the mutations $86 \mathrm{Y}$ and $1246 \mathrm{Y}$ in the $p f m d r 1$ gene and $76 \mathrm{~T}$ in the $p f c r t$ gene are linked to

98 reduced sensitivity to AS-AQ but increased sensitivity to AL, which is thought to be due to differential

99 sensitivity to the amodiaquine and lumefantrine partner drugs rather than the artemisinin. Although the

100 overall efficacy of each drug remains high in Africa, a meta-analysis found that the N86 wild type

101 parasite was associated with a 4-fold increased risk of recrudescence after AL treatment $(9,11)$. All

102 these mutations were also associated with a reduced time to reinfection after AS-AQ treatment, and an

103 increased time to reinfection after AL treatment, although the exact duration of protection was not

104 estimated since this also depends on the local rate of transmission and thus reinfection.

106 The duration of protection can be estimated from clinical trials where reinfection rates are monitored.

107 We previously estimated the mean protection provided by AL at 13.8 days, and DHA-piperaquine at

10829.4 days (4). The duration of protection provided by amodiaquine is not well known, although there

109 are indications that it might confer longer protection than lumefantrine $(23,24)$. Here, we use a

110 statistical analysis of pooled clinical trial data from multiple sites in Africa, explicitly incorporating

111 local transmission intensity as well as drug effects into analyzing the time to reinfection, to estimate the

112 duration of post-treatment prophylaxis after AS-AQ and AL. We use these results in an epidemiological

113 transmission model to establish the differences in public health impact when AS-AQ versus AL is used 114 as first-line drug for P. falciparum case management. 
medRxiv preprint doi: https://doi.org/10.1101/19002741; this version posted July 20, 2019. The copyright holder for this preprint (which was not certified by peer review) is the author/funder, who has granted medRxiv a license to display the preprint in perpetuity.

\section{Results}

117 Duration of protection after $A L$ and $A S-A Q$ treatment in different trial sites

118 We analyzed 4214 individual participant data from randomized clinical trials in 12 sites obtained from

119 the WorldWide Antimalarial Resistance Network (WWARN) data platform (25) with the consent of

120 investigators or sponsors. The median age in the study population was 2.8 years (IQR 1.5-4.2). Patients

121 were followed up until at least day 28 and assessed for the presence of reinfection, using PCR to

122 distinguish reinfecting parasites from recrudescence of the original infection. The time to reinfection in

123 these trials is only in part determined by the duration of protection conferred by the drug. This is

124 because individuals do not immediately become reinfected after the protection ends, but rather enter an

125 "at-risk" state. Thereafter they are reinfected at a rate dependent on the incidence of blood-stage

126 infections in the population (which in turn depends on the entomological inoculation rate (EIR), the

127 number of infectious bites per person per year). We accounted for the differing incidence of infection in

128 the different trial sites using prior information on malaria transmission intensity from the Malaria Atlas

129 Project $(26,27)$, estimated at the location and year in which each trial was carried out. We then

130 employed two statistical approaches: (1) a Hidden Semi-Markov Model (HSMM) to estimate the actual

131 duration of chemoprophylaxis based on the timing of reinfections in patients and (2) a series of

132 accelerated failure time models to provide a better understanding of the factors that modify it (see also

133 Methods).

135 With data pooled across trials, the mean duration of protection against reinfection after AS-AQ 136 treatment was estimated at 15.2 days (95\% CI 12.8-18.4), and after AL treatment, 13.0 days (95\% CI

137 10.7-15.7) (Figure 1). There appeared to be a more gradual transition from a protected to an

138 unprotected state after treatment with AS-AQ compared to AL (Figures 1B \& 1C). However, the site-

139 specific estimates of the duration of post-treatment prophylaxis for each drug were heterogeneous, with

140 mean estimates ranging from 10.2-18.7 days for AS-AQ and 8.7-18.6 days for AL (Figures 1B \& 1C,

141 Table 1). The proportion of patients reinfected in the AS-AQ trial arm was lower than the AL arm in 7

142 sites, while it was higher in the 5 other sites by the end of follow up. (Figure 2). This heterogeneity was

143 confirmed by the posterior estimates of the duration hyper-parameters, which suggested non-zero

144 variance of the random site effects. The heterogeneity existed despite the analysis taking into account

145 variation in EIR, which ranged from an estimated 2 to 117 infectious bites per person per year. While

146 there was, as expected, a reduced total time to reinfection with higher EIR, after accounting for EIR we 
medRxiv preprint doi: https://doi.org/10.1101/19002741; this version posted July 20, 2019. The copyright holder for this preprint (which was not certified by peer review) is the author/funder, who has granted medRxiv a license to display the preprint in perpetuity. It is made available under a CC-BY 4.0 International license.

147 found no trend for duration of drug protection by EIR (Figure S1). Overall the model was able to fit the 148 data well, with the model predicted values being within the $95 \%$ confidence intervals of the proportion 149 of individuals reinfected at each follow up time in almost all sites (Figure 2). Posterior EIR values were 150 mostly in line with the MAP-based prior values but differed considerably for a small number of 151 locations (Figure 3, Table 1). For sensitivity analysis, we tried including additional age-independent 152 variation in exposure to mosquito bites as in a previous analysis (see Methods), since this influences 153 the distribution of reinfection times within a cohort. Such additional variation represents factors such as 154 living close to a breeding site, housing quality, etc. This analysis found similar estimates of the duration 155 of protection after AS-AQ and AL as did the model without additional variation in exposure, at 16.5 156 days (95\% CI 14.2-19.3) and 14.1 days (95\% CI 11.7-16.9), respectively. Therefore, for parsimony we 157 did not include this factor in the final result. 

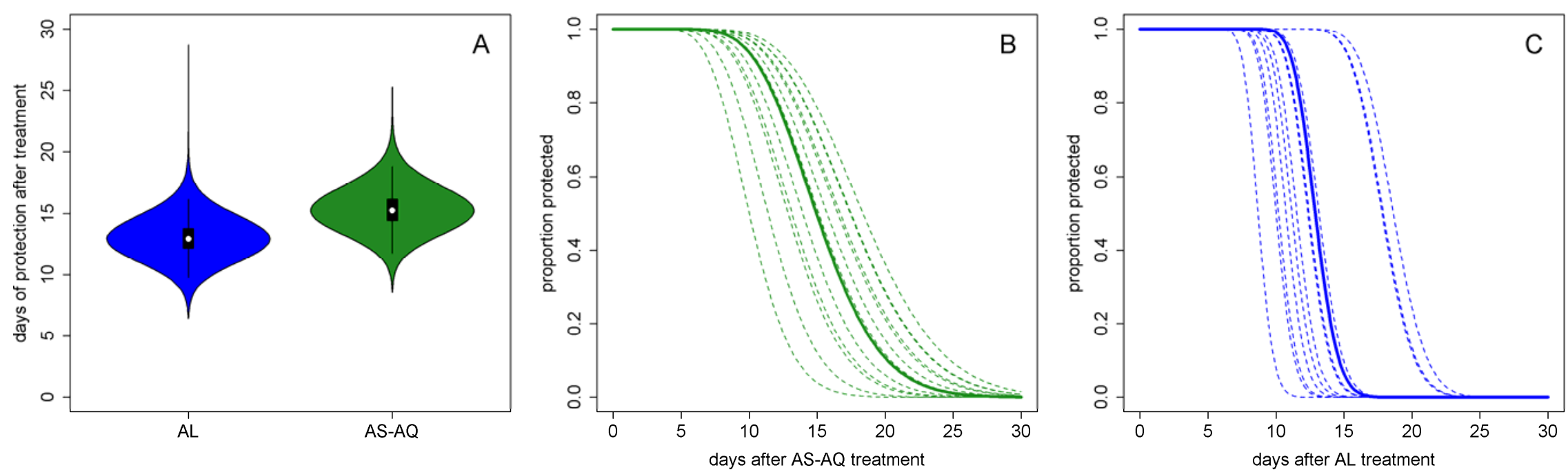

Posterior estimates of the duration of protection (A) and the proportion of the population still protected from reinfection over time since first dose with either AS-AQ (B) or AL (C). In B and C the solid lines show the mean estimate across trial sites, while the dotted lines show the different estimates for each of the 12 trial sites The equations of the lines in $\mathrm{B}$ and $\mathrm{C}$ are reverse cumulative gamma distributions, and can be implemented for example in $\mathrm{R}$ as 1-pgamma(t, shape $=r$, scale $=\lambda)$, where $t$ is time in days, and $r$ and $\lambda$ are the shape and scale parameters of the gamma distribution, respectively. For AL, $r=93.5$ and mean $\lambda=0.139$. For AS-AQ, $r=16.8$ and mean $\lambda=0.906$. The mean of each gamma distribution $r \lambda$ gives the duration of protection from each drug. The site-specific lines can be calculated using the median durations of prophylaxis in Table 1 and the same shape parameter (assumed not to vary between site for each drug). 
169 Proportion of patients reinfected (after PCR correction) during follow up after treatment at day 0 with AL (blue) or AS-AQ (green) in each of 170 the 12 trial sites. Circles show data with 95\% CI, and the lines are the fits of the hidden semi-Markov model in each site. The AL trial arms

171 include in total 2086 individuals, 642 reinfections, and the AS-AQ trial arms, 2128 individuals, 538 reinfections.
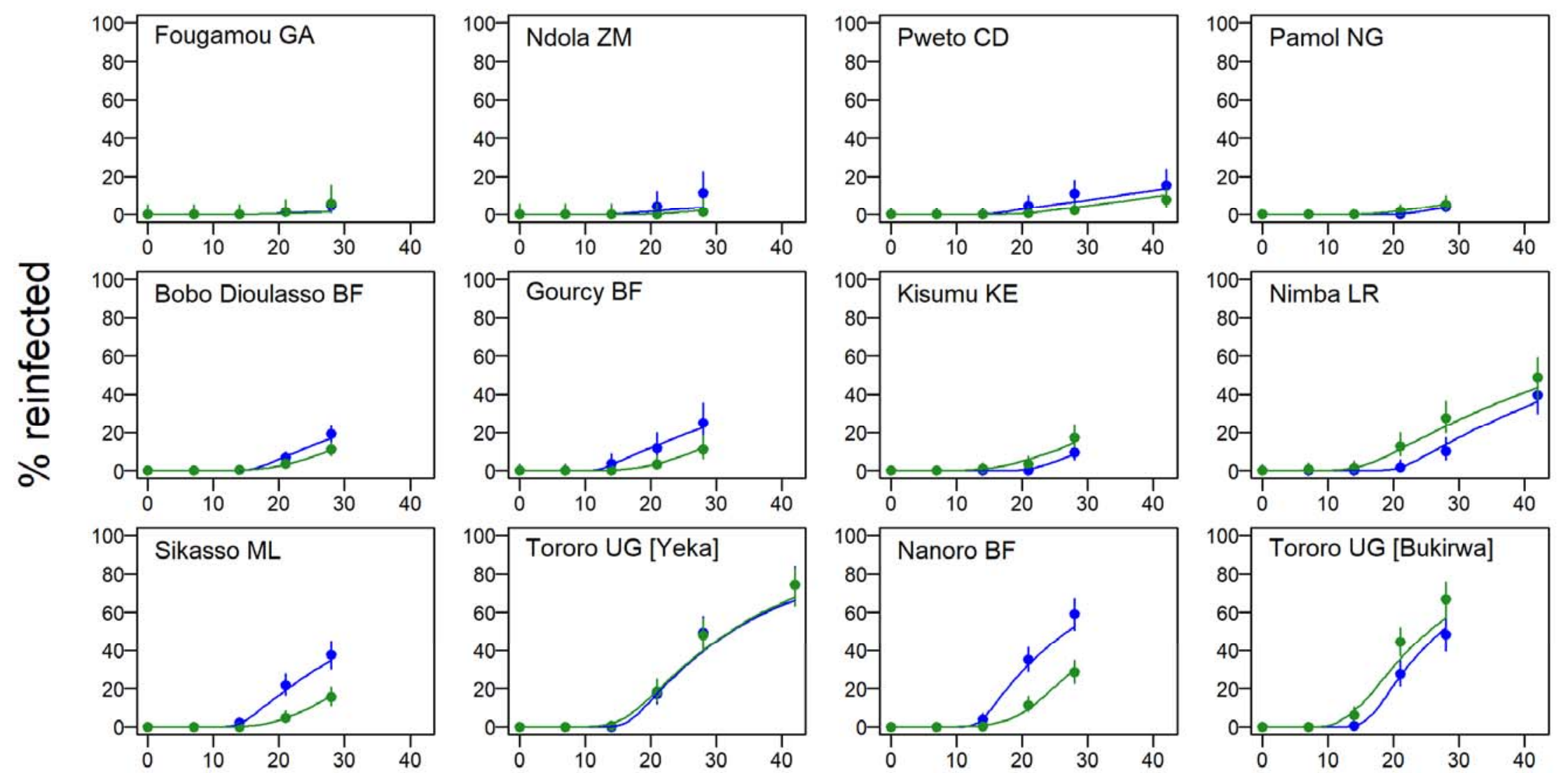

\section{days}




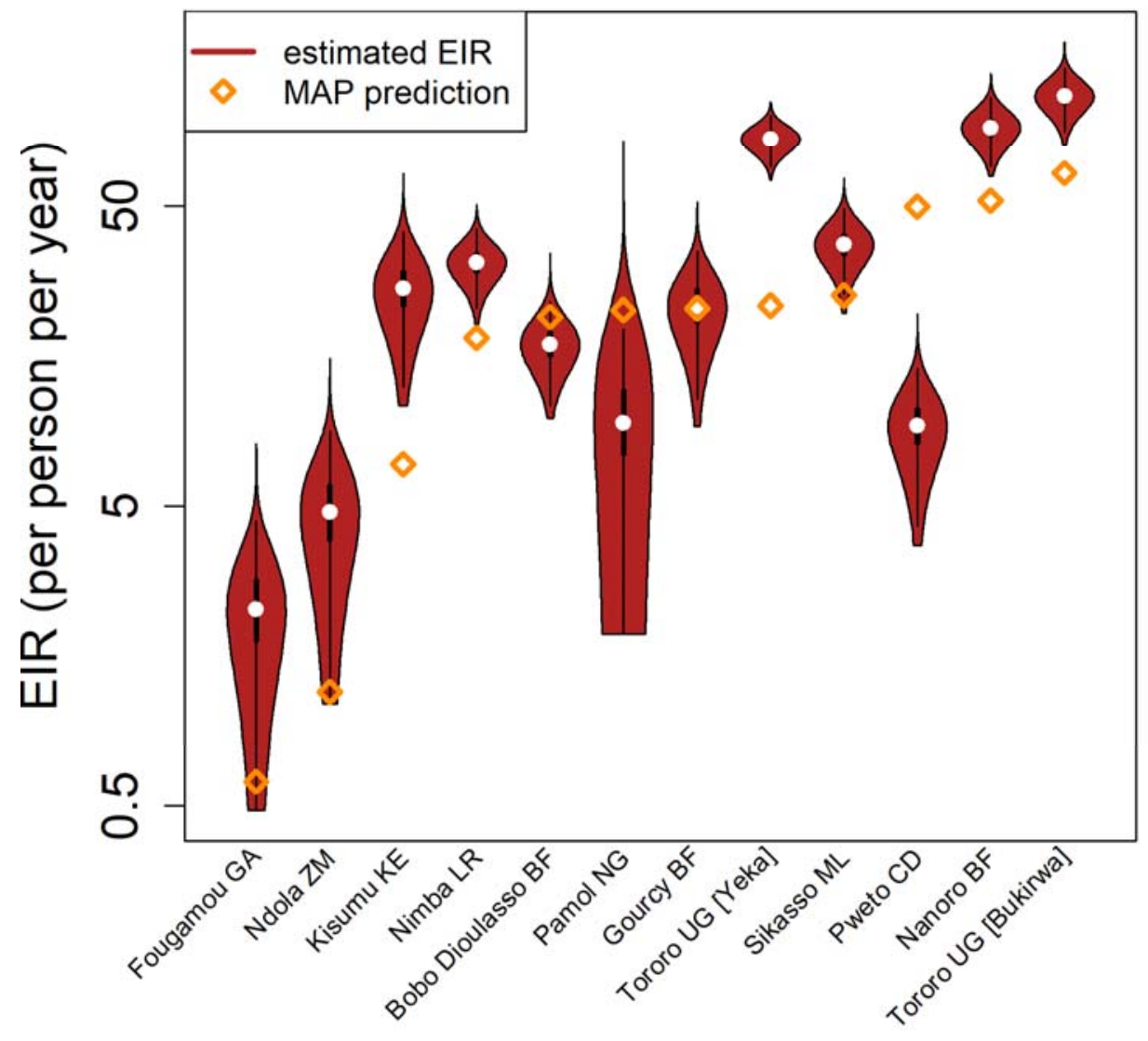


179 transmission intensity, as estimated by the hidden semi-markov model analysis. Prior EIRs are estimated from the Malaria Atlas Project slide-prevalence for each location in the year of the trial $(26,27)$.

\begin{tabular}{|c|c|c|c|c|c|c|c|c|c|c|}
\hline \multirow[t]{2}{*}{ Site } & \multirow[t]{2}{*}{$\begin{array}{l}\text { Country, } \\
\text { year }\end{array}$} & \multirow[t]{2}{*}{ Reference } & \multirow[t]{2}{*}{$\begin{array}{l}\text { N (AL/AS- } \\
\text { AQ) }\end{array}$} & \multirow[t]{2}{*}{$\begin{array}{l}\text { AS-AQ } \\
\text { manufacturer } \\
\text { (formulation), } \\
\text { target AQ dose* }\end{array}$} & \multicolumn{2}{|c|}{\begin{tabular}{|c} 
Days of \\
prophylaxis: \\
posterior \\
median (95\% \\
CI)
\end{tabular}} & \multicolumn{2}{|r|}{ EIR } & \multirow[t]{2}{*}{$\begin{array}{c}\text { Prevalence of } \\
\text { pfmdr1 86Y, \% } \\
\text { (references) }\end{array}$} & \multirow[t]{2}{*}{$\begin{array}{l}\text { Prevalence of } p f c r t \\
76 \mathrm{~T}, \% \text { (references) }\end{array}$} \\
\hline & & & & & $\mathbf{A L}$ & $\begin{array}{l}\text { AS- } \\
\text { AQ }\end{array}$ & $\begin{array}{l}\text { Prior } \\
\text { mean }\end{array}$ & $\begin{array}{l}\text { Posterior } \\
\text { median } \\
(95 \% \mathrm{CI})\end{array}$ & & \\
\hline Fougamou & $\begin{array}{l}\text { Gabon, } \\
\text { 2007-2008 }\end{array}$ & (23) & $68 / 68$ & $\begin{array}{c}\text { Sanofi-Aventis } \\
\text { (FDC Coarsucam) } \\
30 \mathrm{mg} / \mathrm{kg}\end{array}$ & $\begin{array}{l}11.6 \\
(6.0- \\
16.8)\end{array}$ & $\begin{array}{l}13.1 \\
(7.6- \\
18.6)\end{array}$ & 0.6 & $\begin{array}{c}2.3(1.1- \\
4.2)\end{array}$ & $79.5(28)$ & $97.9(29)$ \\
\hline Ndola & $\begin{array}{l}\text { Zambia, } \\
\text { 2007-2009 }\end{array}$ & (23) & $69 / 64$ & $\begin{array}{c}\text { Sanofi-Aventis } \\
\text { (FDC Coarsucam) } \\
30 \mathrm{mg} / \mathrm{kg}\end{array}$ & $\begin{array}{l}10.8 \\
(6.0- \\
14.8)\end{array}$ & $\begin{array}{l}16.1 \\
(9.7- \\
25)\end{array}$ & 1.2 & $\begin{array}{c}4.8(2.4- \\
8.4)\end{array}$ & $\begin{array}{c}\text { No matching } \\
\text { survey }\end{array}$ & 20.8 \\
\hline Pweto & $\begin{array}{l}\text { Democratic } \\
\text { Republic of } \\
\text { Congo }\end{array}$ & (30) & $126 / 129$ & \begin{tabular}{|c} 
Sanofi-Aventis \\
(AS-AQ Winthrop \\
FDC) $30 \mathrm{mg} / \mathrm{kg}$
\end{tabular} & $\begin{array}{l}11.3 \\
(7.8- \\
14.4)\end{array}$ & $\begin{array}{c}17.9 \\
(12.1- \\
25.6)\end{array}$ & 50.0 & $\begin{array}{c}9.3(6.2- \\
13.7)\end{array}$ & $\begin{array}{c}\text { No matching } \\
\text { survey }\end{array}$ & No matching survey \\
\hline Pamol & $\begin{array}{l}\text { Nigeria, } \\
\text { 2007-2008 }\end{array}$ & (23) & $164 / 159$ & $\begin{array}{c}\text { Sanofi-Aventis } \\
\text { (FDC Coarsucam) } \\
30 \mathrm{mg} / \mathrm{kg}\end{array}$ & $\begin{array}{c}17.9 \\
(12.3- \\
22.5)\end{array}$ & $\begin{array}{c}15.4 \\
(10.3- \\
21.7)\end{array}$ & 22.6 & $\begin{array}{l}9.5(4.7- \\
21.6)\end{array}$ & $61.8(31-33)$ & $90.1(34)$ \\
\hline
\end{tabular}




\begin{tabular}{|c|c|c|c|c|c|c|c|c|c|c|}
\hline \multirow[t]{2}{*}{ Site } & \multirow[t]{2}{*}{$\begin{array}{l}\text { Country, } \\
\text { year }\end{array}$} & \multirow[t]{2}{*}{ Reference } & \multirow[t]{2}{*}{$\begin{array}{c}\text { N (AL/AS- } \\
\text { AQ) }\end{array}$} & \multirow[t]{2}{*}{\begin{tabular}{|l} 
AS-AQ \\
manufacturer \\
(formulation), \\
target AQ dose*
\end{tabular}} & \multicolumn{2}{|c|}{\begin{tabular}{|c} 
Days of \\
prophylaxis: \\
posterior \\
median (95\% \\
CI)
\end{tabular}} & \multicolumn{2}{|r|}{ EIR } & \multirow[t]{2}{*}{$\begin{array}{l}\text { Prevalence of } \\
\text { pfmdr1 86Y, \% } \\
\text { (references) }\end{array}$} & \multirow[t]{2}{*}{$\begin{array}{l}\text { Prevalence of } p f c r t \\
76 \mathrm{~T}, \% \text { (references) }\end{array}$} \\
\hline & & & & & $\mathbf{A L}$ & $\begin{array}{l}\text { AS- } \\
\text { AQ }\end{array}$ & $\begin{array}{l}\text { Prior } \\
\text { mean }\end{array}$ & $\begin{array}{c}\text { Posterior } \\
\text { median } \\
(95 \% \mathrm{CI})\end{array}$ & & \\
\hline \begin{tabular}{|l} 
Bobo \\
Dioulasso
\end{tabular} & $\begin{array}{l}\text { Burkina } \\
\text { Faso, 2010- } \\
2012\end{array}$ & $\begin{array}{c}\text { Unpublished } \\
\text { (35) }\end{array}$ & $373 / 372$ & $\begin{array}{c}\text { Sanofi-Aventis } \\
\text { (FDC Coarsucam) } \\
30 \mathrm{mg} / \mathrm{kg}\end{array}$ & $\begin{array}{c}12.5 \\
(10.6- \\
14.4)\end{array}$ & $\begin{array}{l}16.9 \\
(14- \\
19.9)\end{array}$ & 21.5 & $\begin{array}{c}17.4(13.3- \\
23.1)\end{array}$ & $18.0(36,37)$ & $28.5(36-40)$ \\
\hline Gourcy & $\begin{array}{l}\text { Burkina } \\
\text { Faso, 2010- } \\
2012\end{array}$ & $\begin{array}{l}\text { unpublished } \\
\text { (35) }\end{array}$ & $112 / 129$ & $\begin{array}{c}\text { Sanofi-Aventis } \\
\text { (FDC Coarsucam) } \\
30 \mathrm{mg} / \mathrm{kg}\end{array}$ & $\begin{array}{c}8.7 \\
(6.2- \\
10.9)\end{array}$ & $\begin{array}{l}17.8 \\
(13.7- \\
22.1)\end{array}$ & 22.9 & $\begin{array}{c}23.3(15.9- \\
33.7)\end{array}$ & $18.0(36,37)$ & $24.8(37,39)$ \\
\hline Kisumu & $\begin{array}{l}\text { Kenya, } \\
2005\end{array}$ & $\begin{array}{l}\text { Unpublished } \\
\quad(41)\end{array}$ & $179 / 178$ & $\begin{array}{c}\text { Sanofi and } \\
\text { Hoechst Marion } \\
\text { Roussel (Loose } \\
\text { NFDC) } \\
30 \mathrm{mg} / \mathrm{kg}\end{array}$ & $\begin{array}{r}18.6 \\
(15.8- \\
21.2)\end{array}$ & $\begin{array}{c}14.2 \\
(10.9- \\
17.6)\end{array}$ & 6.9 & \begin{tabular}{|c|}
$26.5(18.1-$ \\
$39.6)$
\end{tabular} & $66.6(42-45)$ & $90.3(43,45,46)$ \\
\hline Nimba & $\begin{array}{l}\text { Liberia, } \\
\text { 2008-2009 }\end{array}$ & (47) & $127 / 141$ & $\begin{array}{l}\text { Sanofi-Aventis } \\
\text { (AS-AQ Winthrop } \\
\text { FDC) } 30 \mathrm{mg} / \mathrm{kg}\end{array}$ & $\begin{array}{c}17.9 \\
(15.1- \\
20.6)\end{array}$ & $\begin{array}{l}11.6 \\
(8.8- \\
14.3)\end{array}$ & 18.3 & $\begin{array}{c}32.4(26.1- \\
40)\end{array}$ & $69.4(48)$ & $93.5(48)$ \\
\hline
\end{tabular}




\begin{tabular}{|c|c|c|c|c|c|c|c|c|c|c|}
\hline \multirow[t]{2}{*}{ Site } & \multirow[t]{2}{*}{$\begin{array}{l}\text { Country, } \\
\text { year }\end{array}$} & \multirow[t]{2}{*}{ Reference } & \multirow[t]{2}{*}{$\begin{array}{c}\text { N (AL/AS- } \\
\text { AQ) }\end{array}$} & \multirow[t]{2}{*}{$\begin{array}{l}\text { AS-AQ } \\
\text { manufacturer } \\
\text { (formulation), } \\
\text { target AQ dose* }\end{array}$} & \multicolumn{2}{|c|}{$\begin{array}{c}\text { Days of } \\
\text { prophylaxis: } \\
\text { posterior } \\
\text { median (95\% } \\
\text { CI) }\end{array}$} & \multicolumn{2}{|r|}{ EIR } & \multirow[t]{2}{*}{$\begin{array}{l}\text { Prevalence of } \\
\text { pfmdr1 86Y, \% } \\
\text { (references) }\end{array}$} & \multirow[t]{2}{*}{$\begin{array}{l}\text { Prevalence of } p f c r t \\
76 \mathrm{~T}, \% \text { (references) }\end{array}$} \\
\hline & & & & & $\mathbf{A L}$ & $\begin{array}{l}\text { AS- } \\
\text { AQ }\end{array}$ & $\begin{array}{l}\text { Prior } \\
\text { mean }\end{array}$ & $\begin{array}{c}\text { Posterior } \\
\text { median } \\
(95 \% \mathrm{CI})\end{array}$ & & \\
\hline Sikasso & Mali & (49) & $236 / 233$ & $\begin{array}{c}\text { Sanofi-Aventis } \\
\text { (Coblistered } \\
\text { NFDC. Arsucam) } \\
30 \mathrm{mg} / \mathrm{kg}\end{array}$ & $\begin{array}{l}10.2 \\
(9.0- \\
11.6)\end{array}$ & $\begin{array}{l}18.7 \\
(16.1- \\
21.5)\end{array}$ & 25.2 & $\begin{array}{c}37.2(29.5- \\
46.9)\end{array}$ & $35.5(50)$ & $70.2(50-54)$ \\
\hline Tororo & $\begin{array}{l}\text { Uganda, } \\
\text { 2009-2010 }\end{array}$ & $(55)$ & $190 / 190$ & $\begin{array}{c}\text { Sanofi (AS-AQ } \\
\text { Winthrop FDC) } \\
30 \mathrm{mg} / \mathrm{kg}\end{array}$ & $\begin{array}{c}13.3 \\
(11.8- \\
14.6)\end{array}$ & $\begin{array}{c}13.4 \\
(11.7- \\
15.1)\end{array}$ & 23.3 & $\begin{array}{c}84.2(72.9- \\
96.9)\end{array}$ & $63.9(56-58)$ & $99.6(56,58)$ \\
\hline Nanoro & $\begin{array}{l}\text { Burkina } \\
\text { Faso, 2007- } \\
2008\end{array}$ & (23) & $257 / 273$ & $\begin{array}{c}\text { Sanofi-Aventis } \\
\text { (FDC Coarsucam) } \\
30 \mathrm{mg} / \mathrm{kg}\end{array}$ & $\begin{array}{l}10.1 \\
(9.2- \\
11.1)\end{array}$ & $\begin{array}{c}17.0 \\
(15.0- \\
19.2)\end{array}$ & 52.2 & $\begin{array}{c}91.9(76.2- \\
111.1)\end{array}$ & $31.6(36,59)$ & $67.0(36,40,51,59)$ \\
\hline Tororo & $\begin{array}{l}\text { Uganda, } \\
2005\end{array}$ & (60) & $189 / 195$ & \begin{tabular}{|c|} 
AQ: Parke-David, \\
Pfizer, AS: \\
Sanofi-Aventis \\
(Loose NFDC) 25 \\
mg/kg
\end{tabular} & $\begin{array}{c}12.4 \\
(11.1- \\
13.8)\end{array}$ & $\begin{array}{l}10.2 \\
(8.9- \\
11.6)\end{array}$ & 64.6 & $\begin{array}{l}117.1 \\
(98.4- \\
139.8)\end{array}$ & 79.4 & $96.2(61,62)$ \\
\hline
\end{tabular}


medRxiv preprint doi: https://doi.org/10.1101/19002741; this version posted July 20, 2019. The copyright holder for this preprint (which was not certified by peer review) is the author/funder, who has granted medRxiv a license to display the preprint in perpetuity. It is made available under a CC-BY 4.0 International license .

\section{Factors affecting the duration of prophylaxis}

To investigate which factors affect the duration of prophylaxis after AS-AQ and AL treatment and might explain the heterogeneity between trial sites, the data were further analyzed by accelerated failure time regression models. As expected, EIR (as estimated for each site by the HSMM analysis) was strongly associated with time to reinfection (Table 2). We therefore adjusted for EIR before testing the effect of any additional variables. Treatment arm had a small and significant effect on time to reinfection overall, with AS-AQ being associated with a 1.09-fold increase in time to reinfection (95\% CI 1.05-1.13) compared to AL, after adjusting for log EIR. We explored the effect of molecular markers associated with parasite sensitivity to AL and AS-AQ. These markers were not directly measured during these trials. Instead, for each trial we sought studies close in space and time which measured the prevalence of $p f m d r 1$ 86Y, pfmdr1 1246Y and pfcrt 76T mutations among infected individuals, using recently completed systematic reviews. $(63,64)$ We included matches when the study was conducted in the same country, within $300 \mathrm{~km}$ of the trial site and within 1 year of the trial start or end year. We identified $p f m d r l$ matches to 11 trial sites, and $p f c r t$ matches to 10 sites; however there were too few matched surveys of $p f m d r 11246 Y$ to analyze this third mutation further. Local prevalence of the mutations $p f m d r 186 \mathrm{Y}$ and $p f c r t 76 \mathrm{~T}$ significantly altered the association between drug and time to reinfection. AS-AQ was associated with a significant 1.37 (95\% CI 1.28-1.47)-fold increase in time to reinfection compared to AL when pfmdrl $86 \mathrm{Y}$ prevalence was $20 \%$ (the lowest level observed in the trial sites), but a significantly shorter time to reinfection than AL when $p f m d r 186 \mathrm{Y}$ was $80 \%$ (ratio of reinfection times AS-AQ vs AL=0.89 95\% CI 0.84-0.94). Similarly, AS-AQ was associated with a 1.54 (95\% CI 1.38-1.71)-fold increase in time to reinfection compared to AL when pfcrt 76T prevalence was $20 \%$, but a 1.06 (95\% CI 1.03-1.10)-fold change when $p f c r t 76 \mathrm{~T}$ prevalence was $80 \%$. Other factors that were significantly associated with longer time to reinfection when adjusting each factor only for $\log$ EIR were younger age and higher dose of lumefantrine (mg per $\mathrm{kg}$ ) (Table 2). Increasing age amongst children was associated with a shorter time to reinfection in a non-linear manner, such that the change in reinfection time with age was most rapid at younger ages, consistent with observed biting patterns by age (65). There was a trend for shorter time to reinfection in underweight individuals and when the loose non-fixed-dose combination (NFDC) formulation of AS-AQ was used, though the association was not statistically significant after adjusting for log EIR. 
medRxiv preprint doi: https://doi.org/10.1101/19002741; this version posted July 20, 2019. The copyright holder for this preprint (which was not certified by peer review) is the author/funder, who has granted medRxiv a license to display the preprint in perpetuity.

214 lumefantrine dose (mg per $\mathrm{kg}$ ), local $p f m d r 186 \mathrm{Y}$ prevalence and $p f c r t 76 \mathrm{~T}$ prevalence remained at least

215 borderline significant predictors of time to reinfection (Tables $3 \& \mathrm{~S} 1$ ). However, pfmdr1 86Y

216 prevalence and $p f c r t 76 \mathrm{~T}$ prevalence were so closely correlated (Figure S2) that their effects could not

217 be distinguished from each other in the absence of haplotype data, and we built separate multivariable

218 models to look at each mutation. In the $\mathrm{AL}$ arm, both the $p f m d r 186 \mathrm{Y}$ and the $p f c r t 76 \mathrm{~T}$ mutations were

219 associated with a 1.04-fold increase in time to reinfection per $10 \%$ increase in their prevalence

$220(\mathrm{p}=0.052$ and $\mathrm{p}=0.005$, respectively) after adjusting for EIR, age and lumefantrine dose.

222 In the AS-AQ arm, EIR, age and $p f m d r 186 \mathrm{Y}$ prevalence remained significantly associated with time to 223 reinfection overall, with $86 \mathrm{Y}$ associated with a 0.97 -fold decrease in reinfection time per $10 \%$ increase 224 in prevalence $(\mathrm{p}=0.011)$. For sensitivity analysis we repeated the regression model including only the 225 trial sites which used the fixed-dose combination (FDC) formulation of AS-AQ, and here the effect of $226 p f m d r 186 \mathrm{Y}$ was no longer statistically significant although the effect size remained similar $(0.98(95 \%$ 227 CI 0.95, 1.01)-fold change in reinfection times, $\mathrm{p}=0.159$ ). Again, we looked at $p f c r t$ 76T in a separate 228 multivariable model in the AS-AQ arm; here it was no longer significantly associated with reinfection 229 time after adjusting for EIR and age, although there was still a trend for shorter time to reinfection as $23076 \mathrm{~T}$ prevalence increased ( 0.98 -fold change in time to reinfection per $10 \%$ increase in $76 \mathrm{~T}$ prevalence; $23195 \%$ CI $0.95,1.01)$.

233 We further investigated the relationship of $p f m d r 186 \mathrm{Y}$ and $p f c r t 76 \mathrm{~T}$ prevalence with prophylactic time 234 by examining the site-specific estimates from the hidden semi-Markov model (HSMM) analysis. The 235 mean duration of protection from the HSMM (which is adjusted for EIR and age) was 16.9-17.8 days 236 for AS-AQ in the trial sites with the lowest recorded 86Y and 76T prevalence (Bobo-Dioulasso and 237 Gourcy in Burkina Faso), while it was 10.2-13.1 days in the trial sites with the highest 86Y and 76T 238 prevalence (Tororo, Uganda and Fougamou, Gabon) (Figure 4A \& 4C). Conversely, the duration of 239 protection provided by AL was 8.7-12.5 days in the sites with the lowest 86Y and 76T prevalence, 240 while in sites with higher $86 \mathrm{Y}$ and $76 \mathrm{~T}$ prevalence, the duration of AL protection was variable but 241 generally higher, at 11.5-18.6 days (Figure 4B \& 4D). 
medRxiv preprint doi: https://doi.org/10.1101/19002741; this version posted July 20, 2019. The copyright holder for this preprint (which was not certified by peer review) is the author/funder, who has granted medRxiv a license to display the preprint in perpetuity.

It is made available under a CC-BY 4.0 International license.

243 Table 2 - Risk factors for reinfection: analysis adjusted for EIR only.

244 Data from 2130 individuals in the AS-AQ trial arms and 2090 in the AL trial arms were analyzed using 245 accelerated failure-time analysis. Regression coefficients are the ratio of time to reinfection, such that a 246 coefficient $>1$ indicates a longer time to reinfection. All results are adjusted for log EIR. Site-level 247 random effects were included unless otherwise indicated. Models assume a log-normal time to 248 reinfection.

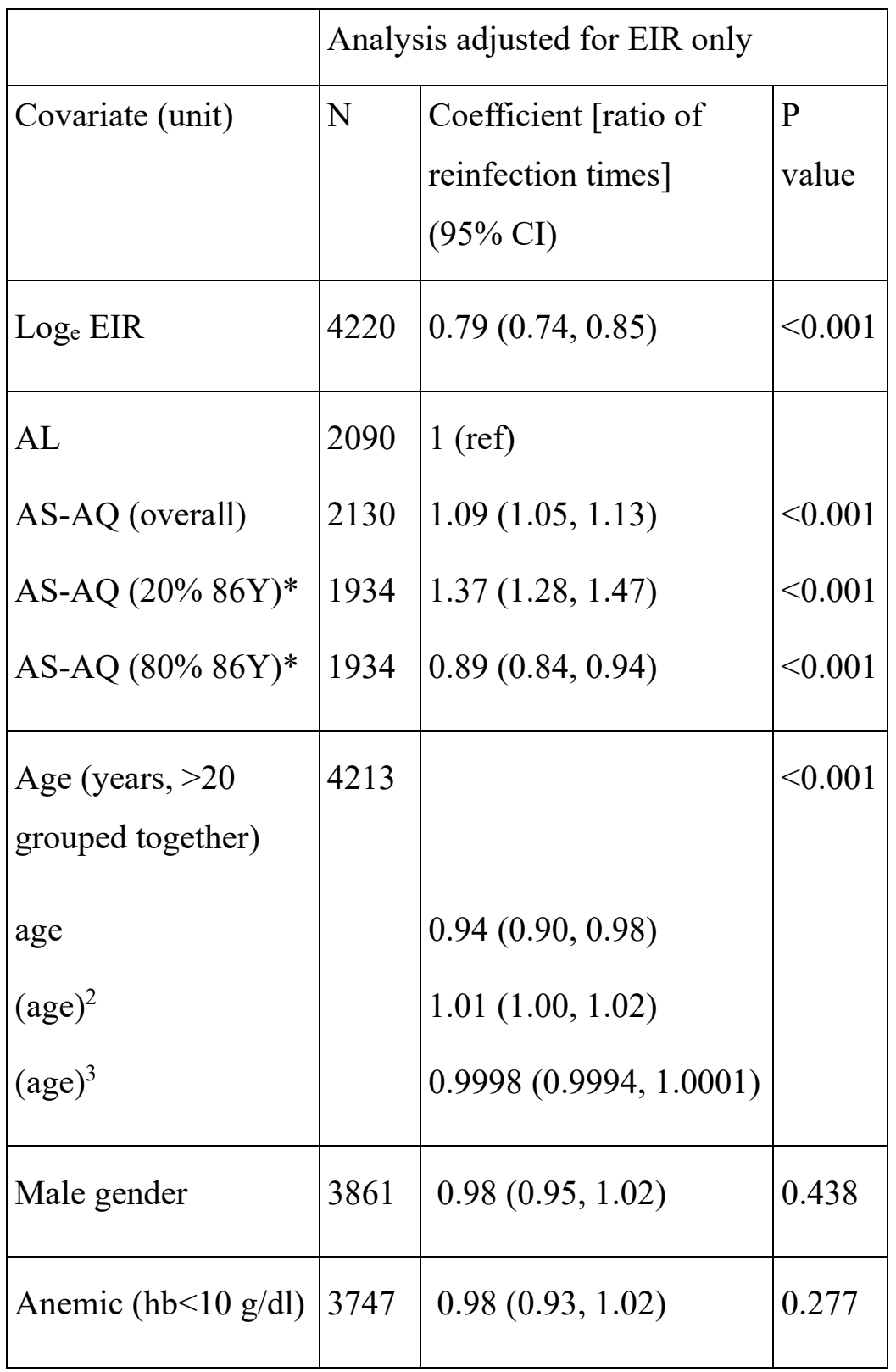




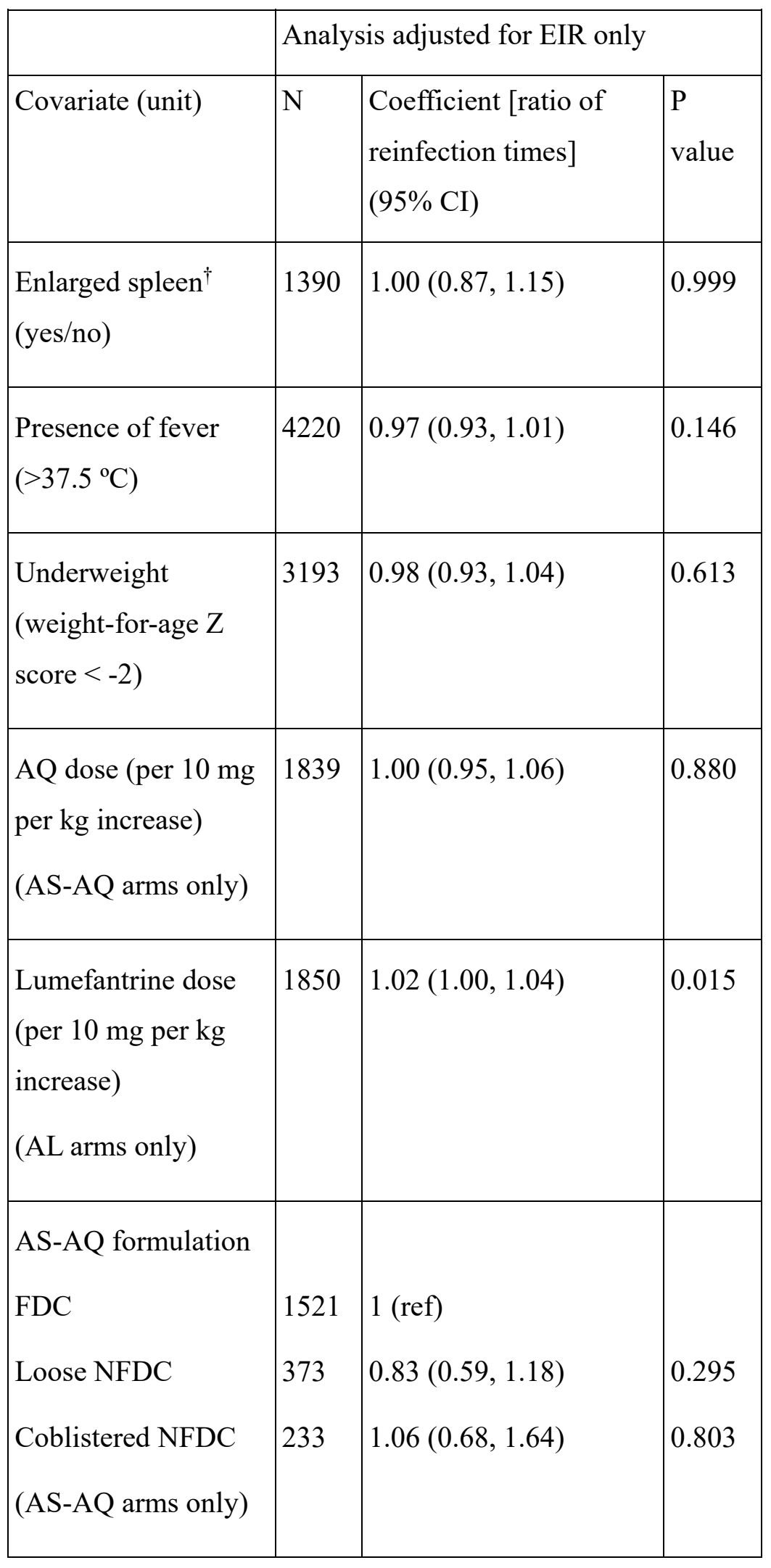




\begin{tabular}{|l|l|l|l|}
\hline \multicolumn{3}{|l|}{ Analysis adjusted for EIR only } \\
\hline Covariate (unit) & $\mathrm{N}$ & $\begin{array}{l}\text { Coefficient [ratio of } \\
\text { reinfection times] } \\
(95 \% \text { CI) }\end{array}$ & P value \\
\hline $\begin{array}{l}\text { pfmdr1 86Y } \\
\text { prevalence (per 10\% } \\
\text { increase) }\end{array}$ & 1891 & $1.03(0.99,1.07)$ & 0.091 \\
AL arm $\$$ & 1934 & $0.96(0.94,0.98)$ & $<0.001$ \\
AS-AQ arm & 1964 & $1.03(1.00,1.07)$ & 0.037 \\
\hline $\begin{array}{l}\text { pfcrt 76T prevalence } \\
\text { (per 10\% increase) } \\
\text { AL arm }\end{array}$ & 2001 & $0.97(0.95,1.00)$ & 0.052 \\
AS-AQ arm & & & \\
\hline
\end{tabular}

* In a model including $\log _{10}$ EIR, drug, pfmdr1 86Y prevalence (per 10\% increase) and interaction 253 between drug and pfmdrl 86Y prevalence.

$254 \dagger$ Site-level random effects not included because many sites did not measure this covariate.

$255 \$ \mathrm{P}$ value interaction between drug and $p f m d r 186 \mathrm{Y}$ vs $\mathrm{N} 86$ prevalence $<0.001$, P value interaction 256 between drug and $p f c r t 76 \mathrm{~T}$ vs $\mathrm{K} 76$ prevalence $<0.001$ 
medRxiv preprint doi: https://doi.org/10.1101/19002741; this version posted July 20, 2019. The copyright holder for this preprint (which was not certified by peer review) is the author/funder, who has granted medRxiv a license to display the preprint in perpetuity.

258 Table 3. Risk factors for reinfection: multivariable analysis with $p f m d r 1$.

259 Data from 1934 individuals in the AS-AQ trial arms and 1655 in the AL trial arms were analyzed using

260 accelerated failure-time analysis. Regression coefficients are the ratio of time to reinfection, such that a

261 coefficient $>1$ indicates a longer time to reinfection. Covariates significantly associated with reinfection

262 time after adjusting for EIR $(\mathrm{p}<0.05)$ were included in the final model. The prevalence of $p f c r t 76 \mathrm{~T}$ also

263 had a significant effect in a multivariable model with the same covariates (Table S1) but could not be

264 included in the same model with pfmdrl 86Y due to strong correlation between the two variables.

265 Models assume a log-normal time to reinfection and random site effects.

\begin{tabular}{|c|c|c|c|c|}
\hline \multirow[b]{2}{*}{ Covariate (unit) } & \multicolumn{2}{|c|}{$\begin{array}{l}\text { AL multivariable model }(\mathrm{N}=1655) \text { : } \\
\text { EIR, age, dose, pfmdr1 86Y }\end{array}$} & \multicolumn{2}{|c|}{$\begin{array}{l}\text { AS-AQ multivariable model }(\mathrm{N}=1934) \\
\text { EIR, age, pfmdr1 86Y }\end{array}$} \\
\hline & $\begin{array}{l}\text { Coefficient [ratio of } \\
\text { reinfection times] } \quad(95 \% \\
\text { CI })\end{array}$ & P value & $\begin{array}{l}\text { Coefficient [ratio of reinfection } \\
\text { times] } \quad(95 \% \mathrm{CI})\end{array}$ & P value \\
\hline $\log _{e}$ annual EIR & $0.81(0.74,0.90)$ & $<0.001$ & $0.81(0.75,0.87)$ & $<0.001$ \\
\hline $\begin{array}{l}\text { Age (years, }>20 \\
\text { grouped together) } \\
\text { age } \\
(\text { age })^{2} \\
(\text { age })^{3}\end{array}$ & $\begin{array}{l}1.01(0.93,1.09) \\
1.00(0.99,1.02) \\
1.0001(0.9992,1.0009)\end{array}$ & $<0.001$ & $\begin{array}{l}0.94(0.88,1.00) \\
1.01(1.00,1.02) \\
0.9998(0.9993,1.0003)\end{array}$ & $<0.001$ \\
\hline $\begin{array}{l}\text { Lumefantrine } \\
\text { dose (per } 10 \mathrm{mg} \\
\text { per kg increase) } \\
\text { (AL arms only) }\end{array}$ & $1.03(1.01,1.06)$ & 0.002 & - & - \\
\hline $\begin{array}{l}\text { pfmdrl } 86 \mathrm{Y} \\
\text { prevalence (per } \\
10 \% \text { increase) }\end{array}$ & $1.04(1.00,1.09)$ & 0.059 & $0.97(0.94,0.99)$ & 0.012 \\
\hline
\end{tabular}


medRxiv preprint doi: https://doi.org/10.1101/19002741; this version posted July 20, 2019. The copyright holder for this preprint (which was not certified by peer review) is the author/funder, who has granted medRxiv a license to display the preprint in perpetuity.

267 Figure 4. Duration of protection after treatment with (A \& C) AS-AQ and (B \& D) AL, according to

268 local $p f m d r 1$ N86Y (A \& B) and pfcrt K76T mutation prevalence (C \& D). Median posterior estimates

269 of duration of protection from hidden Markov model analysis are shown (points) with 95\% credible

270 intervals (vertical lines). Local $p f m d r 1 \mathrm{~N} 86 \mathrm{Y}$ and $p f c r t \mathrm{~K} 76 \mathrm{~T}$ mutation prevalences are from matched

271 surveys within 1 year and $300 \mathrm{~km}$ in the same country as each trial. Horizontal lines indicate the $95 \%$

272 confidence intervals of the mutation prevalence estimates.
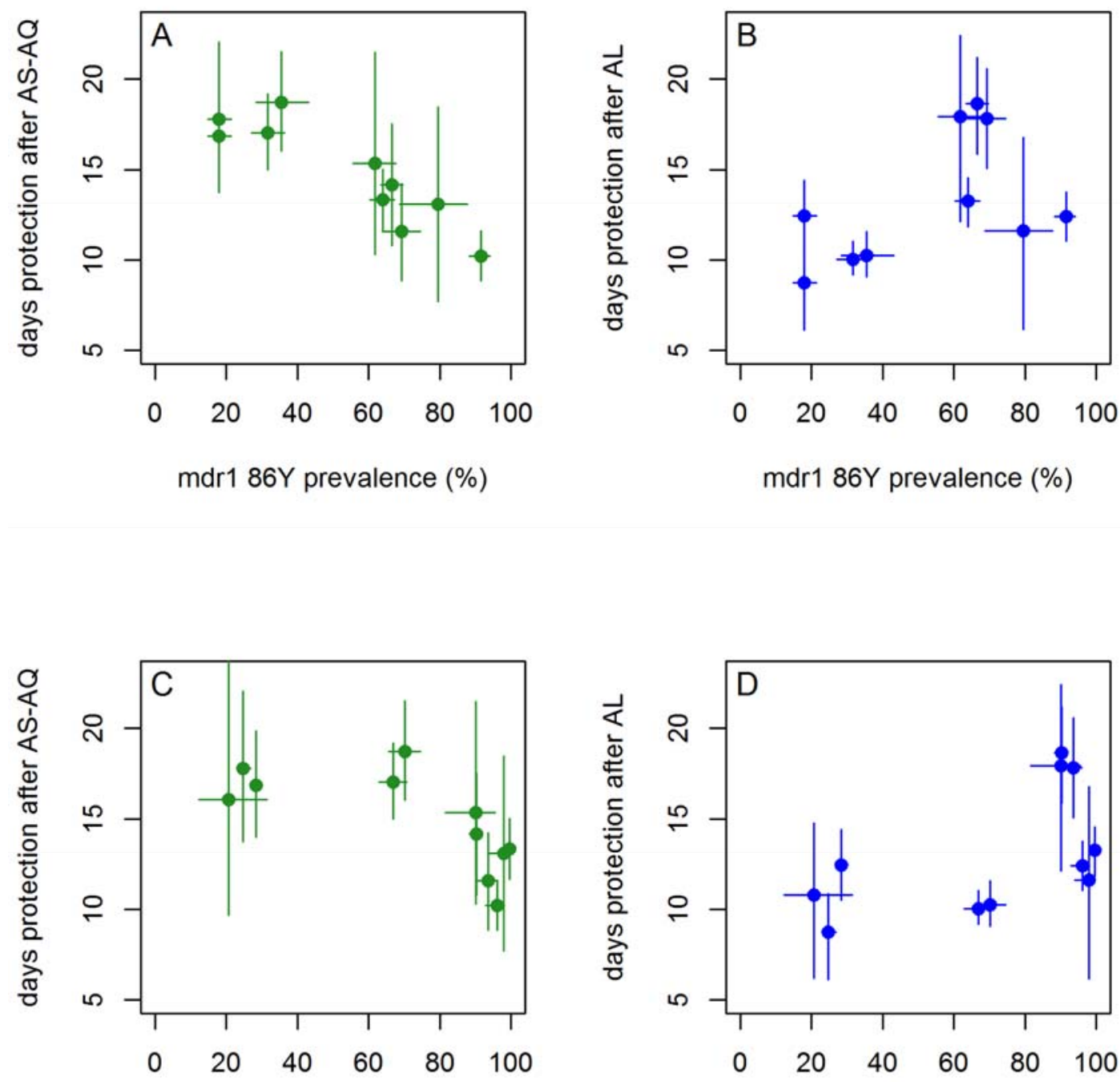

crt $76 \mathrm{~T}$ prevalence (\%)

crt $76 \mathrm{~T}$ prevalence (\%) 
medRxiv preprint doi: https://doi.org/10.1101/19002741; this version posted July 20, 2019. The copyright holder for this preprint (which was not certified by peer review) is the author/funder, who has granted medRxiv a license to display the preprint in perpetuity.

274 Model-estimated population-level impact of using $A S-A Q$ versus $A L$ as first-line treatment

275 The duration of prophylaxis provided by an antimalarial used as first-line treatment affects overall clinical

276 incidence in a population because (a) it provides individual-level protection against reinfection and (b)

277 prevention of reinfection reduces the total prevalence of infection in a population, and therefore onward

278 transmission from infected individuals. Simulations comparing the public-health impact of using either AL

279 or AS-AQ as first-line drug were run using an existing individual-based age-structured mathematical model

280 of Plasmodium falciparum transmission. The model incorporates clinical episodes by age and exposure

281 which have been fitted to data in a wide variety of settings.(66) We simulated low, medium and high

282 transmission areas (pre-intervention slide prevalence in $2-10$ year olds $=5 \%, 15 \%$ and $50 \%$, respectively),

283 with and without seasonal variation in transmission (Figure S3). Given the variation in prophylactic time

284 between areas, we chose to use estimates from two of the trial sites with the most contrasting effects of the

285 two drugs (Figure 5). In the trial in Gourcy, Burkina Faso in 2010-2012, there was low local prevalence of

286 the $p f m d r 186 \mathrm{Y}$ mutation (18\%) and the pfcrt 76T mutation (25\%), with a correspondingly long estimated

287 duration of protection by AS-AQ at 17.8 days, approximately twice as long as the estimated duration of

288 protection by AL in this site: 8.7 days. Using the prophylactic profiles estimated in this trial site (Figure

289 5A), we introduced either AL or AS-AQ as first-line treatment into our simulation, assuming $80 \%$ of

290 clinical episodes in all ages are treated with this drug, and the total number of clinical episodes occurring in

291 0-5 year olds over the subsequent 5 years was compared between the two treatments. The longer

292 prophylactic time of AS-AQ reduced clinical episodes in all transmission scenarios (Figure 5B \& 5C), but

293 was most pronounced in simulations with higher, very seasonal transmission. When slide-prevalence was

$29450 \%$ and transmission was seasonal, using AS-AQ rather than AL prevented 1.6 clinical episodes per child 295 over the 5 years (Figure 5B) (14\% of all clinical episodes; Figure 5C). When considering all age groups, an 296 estimated $10 \%$ of clinical episodes were prevented (Figure S4).

298 In Nimba in Liberia (trial conducted 2008-2009) the local prevalence of $p f m d r 186 \mathrm{Y}$ and $p f c r t 76 T$ were 299 much higher at $69 \%$ and $95 \%$, and the duration of prophylaxis provided by AS-AQ was estimated at only 30011.6 days, while the AL prophylactic time was 17.9 days (Figure 5D). Here, using AS-AQ rather than AL 301 increased the cumulative number of clinical episodes per 0-5 year old child by up to 1.1 over the 5 year 302 simulated period (an increase of 11\%), with the largest difference between drugs again observed in the very 303 seasonal, high transmission scenario (Figure 5E \& 5F). When considering all age groups, clinical episodes 304 increased by up to $8 \%$ (Figure S4). 
medRxiv preprint doi: https://doi.org/10.1101/19002741; this version posted July 20, 2019. The copyright holder for this preprint (which was not certified by peer review) is the author/funder, who has granted medRxiv a license to display the preprint in perpetuity.

It is made available under a CC-BY 4.0 International license.

306 It is uncertain whether there is any difference in human infectiousness after treatment with AL versus AS-

307 AQ. We therefore ran the simulations twice, assuming firstly that patients are equally infectious after

308 treatment with either ACT, and secondly assuming that patients treated with AS-AQ are twice as infectious, 309 in accordance with previous studies $(47,67)$. In both settings, there was minimal difference in impact on

310 clinical episodes $(<1 \%)$ if we assumed that patients treated with AL were half as infectious as those treated

311 with AS-AQ, compared with the scenarios where infectiousness was assumed to be equal after each

312 treatment (results not shown). This is because even if there is some difference between treatments, both are

313 estimated to have a high impact on gametocytes. Therefore, at a population level, transmission to

314 mosquitoes is dominated by untreated infections which are thought to last on average about 6 months,

315 according to our model assumptions and parameters. $(66,68,69)$ 

treatment, estimated by the transmission model analysis, contrasting areas with low (A-C) or high (D-F) pfmdr1 86Y and pfcrt 76T prevalence. (A) The estimated proportion of individuals protected over time since treatment by AL or AS-AQ in Gourcy, Burkina Faso where $86 \mathrm{Y}$ and $76 \mathrm{~T}$ prevalences are low (18\% and 25\%, respectively) and amodiaquine provides longer chemoprophylaxis than lumefantrine or (D) Nimba, Liberia where $86 \mathrm{Y}$ and $76 \mathrm{~T}$ prevalences are high (69\% and 95\%, respectively) and the prophylactic times are reversed so that lumefantrine provides longer chemoprophylaxis than amodiaquine. (B) and (C) show the model-estimated impact in children aged 0-5 years of using AS-AQ rather than AL as first-line treatment in the whole population, using the prophylactic profiles in (A). The outcomes are (B) the difference $(C)$ the $\%$ difference in the cumulative number of clinical episodes occurring during the 5 years after implementing either drug at $80 \%$ coverage; here AS-AQ is predicted to decrease clinical incidence compared with AL. Orange bars show the impact in non-seasonal settings, while red shows the impact in a seasonal setting (see Methods). (E) and (F) show the corresponding results using the prophylactic profiles in (D); here AS-AQ is predicted to increase clinical incidence compared with AL. 

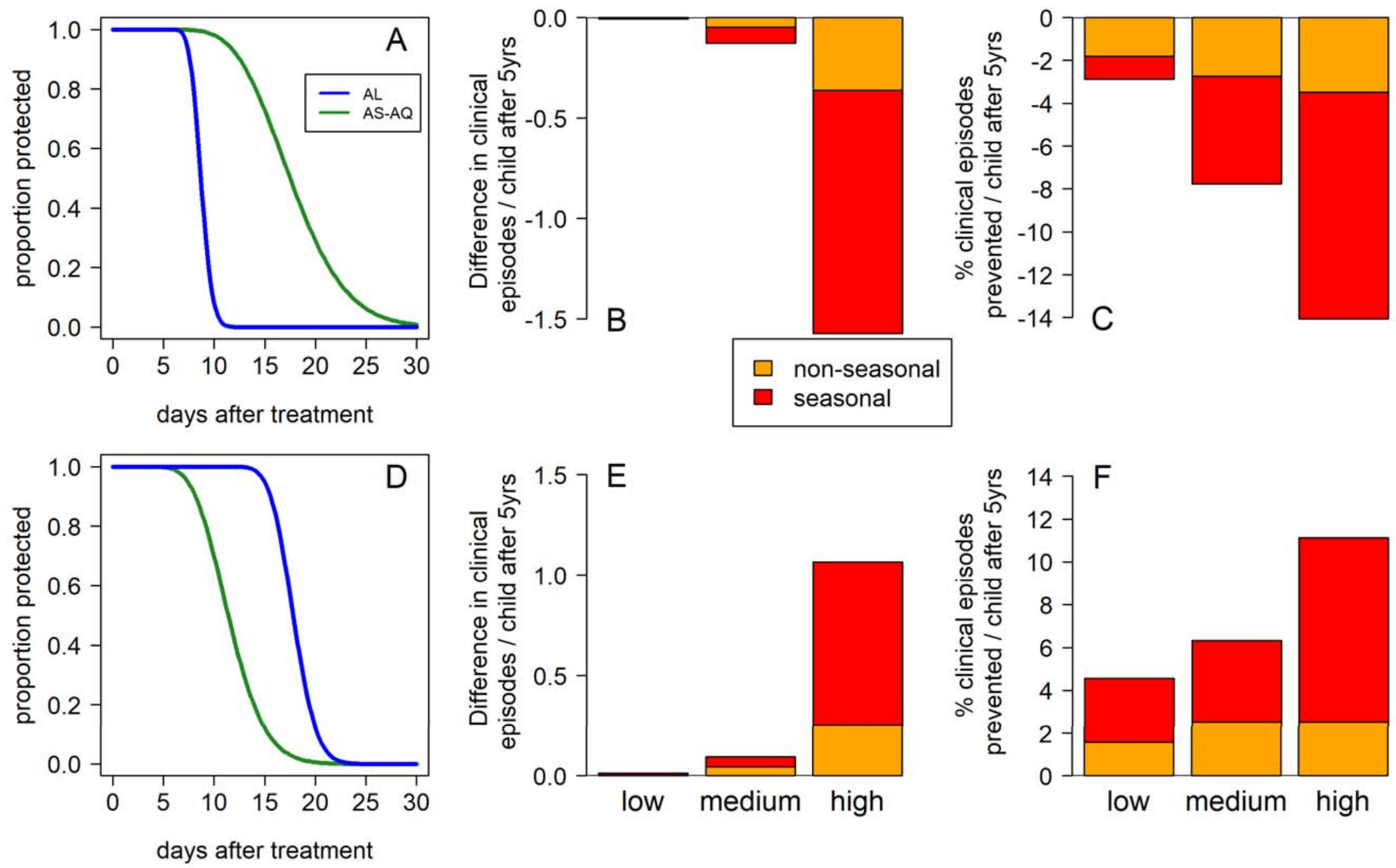

days after treatment 


\section{Discussion}

330 In this analysis of clinical trials from 12 sites in Africa, we initially estimated that AS-AQ provided a 331 slightly longer duration of post-treatment prophylaxis than AL (15.2 versus 13.0 days) when all data were 332 pooled together. However, the duration of protection varied considerably between trial sites. In some 333 locations AS-AQ provided up to an estimated 19 days of protection, $\sim 2$-fold longer than AL, while in other 334 trial sites the reverse was true, with AL providing up to 19 days of protection, which was up to 1.5-fold 335 longer than AS-AQ. This difference between sites appeared to be in part explained by the local prevalence 336 of $p f m d r 186 \mathrm{Y}$ and $p f c r t 76 \mathrm{~T}$ at the time of the trial, with AS-AQ providing better protection where wild 337 type parasites with N86 and K76 genotypes were predominant, and AL performing better where $86 \mathrm{Y}$ and $33876 \mathrm{~T}$ mutants were common. This is consistent with previous studies demonstrating the collateral sensitivity 339 of parasites with these different $p f m d r 1$ and $p f c r t$ genotypes to AL and AS-AQ. Our analysis extends 340 previous work $(9,11,70)$ by explicitly estimating the duration of protection provided by each drug in sites 341 with different prevalence of $86 \mathrm{Y}$ and $76 \mathrm{~T}$ mutants, also taking into account the different EIRs across the 342 trial sites so as to distinguish the effect of the drugs from that of the local transmission intensity on the time 343 to reinfection.

345 Our transmission modelling suggests that the difference in duration of protection between the two drugs in 346 areas with very low or very high $86 \mathrm{Y}$ and $76 \mathrm{~T}$ prevalence can have a public health impact, especially where 347 malaria transmission is high and seasonal. We estimate that up to $14 \%$ of clinical episodes could be 348 prevented in 0-5 year old children by using the drug providing optimal protection in a given setting, due to 349 both individual protection from reinfection and population level reduction in transmission (when $80 \%$ of 350 clinical episodes receive treatment). Countries with low $(<20 \%)$ or high $(>80 \%)$ prevalence of $86 \mathrm{Y}$ and $76 \mathrm{~T}$ 351 and intense transmission could consider the benefit of longer duration of protection if choosing between AL and AS-AQ policies. Using a first line treatment with longer duration of protection is potentially a cost353 effective way of reducing clinical cases and infections,(4) given the comparable price of AL and AS-AQ 354 (71). Compared to published estimates, both AL and AS-AQ provided a shorter duration of protection than dihydroartemisinin-piperaquine (estimated at 29.4 days of $>50 \%$ protection (4)), which is predicted to prevent up to $15 \%$ more cases than $\operatorname{AL}(4,72)$. widespread use of chloroquine, have been in decline in many parts of Africa. The decline has occurred 
medRxiv preprint doi: https://doi.org/10.1101/19002741; this version posted July 20, 2019. The copyright holder for this preprint (which was not certified by peer review) is the author/funder, who has granted medRxiv a license to display the preprint in perpetuity. it is made available under a CC-BY 4.0 International license .

360 fastest in countries using AL, consistent with the expected direction of selection (64). The efficacy of AS-

361 AQ appears to have improved in some countries and there is interest in increasing the use of the drug 362 regimen where $86 \mathrm{Y}$ and $76 \mathrm{~T}$ prevalence have declined (55). However, there are many other considerations 363 to choosing a first-line treatment, such as side effects, tolerability, cost of implementing a new policy, etc.

364 Amodiaquine is also widely used together with sulfadoxine-pyrimethamine (SP) in seasonal malaria 365 chemoprevention (SMC) programmes in children in the Sahel region of Africa, given to 12 million children 366 under five years of age in 2016 (73). Our results could be used together with information on the

367 chemoprophylaxis provided by SP, to inform potential changes in the efficacy of SMC as 86Y and 76T 368 prevalence change. This may be particularly important in areas with partial SP resistance. Currently, WHO 369 recommends not using drug regimens containing AQ or SP as first line treatment in countries implementing 370 SMC (74). Indeed most SMC countries currently use AL as first-line (7). Our results support previous 371 findings suggesting that selective pressures exerted by AL and AS-AQ may counteract each other. However, 372 our results suggest it would not be possible to achieve maximal prophylactic effect of either AL or AS-AQ 373 at the same time in a given setting. Triple ACT which combine an artemisinin derivative with both 374 lumefantrine and amodiaquine are currently in trials (75), and would be likely to ensure longer prophylactic 375 protection.

377 Our finding that the $p f m d r 186 \mathrm{Y}$ and $p f c r t 76 \mathrm{~T}$ mutations are associated with a longer time to reinfection 378 after AL treatment and a shorter time after AS-AQ is consistent with a previous meta-analysis, where 379 individual patient data on genotypes post-treatment were available. $(9,11)$ We did not include such a wide 380 range of studies as the previous meta-analysis because our methods required that we estimate the EIR for 381 each included trial site, which is only possible when sufficient numbers of reinfections are observed per site 382 and we included only randomized trials. The advantage of our approach, however, is that we can obtain 383 estimates of prophylactic times after adjusting for the local transmission intensity. One limitation of our 384 study was that we did not have individual level data on genotypes pre and post-treatment, which were not measured in the trials we included here. This might have allowed a more precise estimate of the effect of 386 mutations on prophylactic time, and ideally comparison of $p f c r t$ and $p f m d r l$ haplotypes. Also, while we 387 matched trials to the closest possible measures of mutation prevalence, these may not reflect the prevalence 388 in the trial sites which can vary over space and time. We could not distinguish separate effects of $86 \mathrm{Y}$ and $38976 \mathrm{~T}$ in this analysis due to the close correlation of their prevalence. Other previous meta-analyses have 390 examined the effect of dosing and other covariates on the probability of recrudescence after AL (10) and 
medRxiv preprint doi: https://doi.org/10.1101/19002741; this version posted July 20, 2019. The copyright holder for this preprint (which was not certified by peer review) is the author/funder, who has granted medRxiv a license to display the preprint in perpetuity. It is made available under a CC-BY 4.0 International license .

391 AS-AQ (12). The trends in our analysis looking at reinfection as the outcome rather than recrudescence

392 agree well with these previous studies; in particular the use of loose NFDC formulation of AS-AQ was 393 associated with reduced time to reinfection although it was not statistically significant after adjusting for 394 EIR. Of the three studies using loose NFDC, two of these showed a longer prophylactic time by AL, 395 compared to two out of the remaining 9 studies which used FDC.

397 Our estimate of the mean duration of prophylaxis after AL at 13.0 days is in good agreement with our 398 previous estimate of 13.8 days which was obtained from analysis of a completely different dataset of 399 clinical trials in six sites in Africa (4) (although the impact of 86Y and 76T was not previously

400 investigated). In the current analysis we found a more rapid decline of protection over time after $\mathrm{AL}$ 401 treatment than AS-AQ (Figure 1), and a similar rapid decline after AL was seen in our previous analysis.

402 The resolution of data informing this profile of post-treatment prophylaxis is not perfect, with most patients 403 observed only weekly after day 7. In 4 of the trial sites in the current analysis, no tests for reinfection were 404 done until day 14 (23). Nevertheless given the very low proportion of individuals reinfected at earlier times 405 in the other sites it is unlikely that many reinfections were missed. In most trials patients were followed up 406 until day 28 , and differential reinfection rates may have been missed after this time. We lacked data from a 407 control arm to parameterize the proportion of individuals reinfected over time in the absence of treatment. If 408 our model underestimates the rate of increase in the proportion of individuals reinfected in the absence of 409 treatment, it could overestimate the rapid drop off in protection in the AL trial arms to compensate. There is 410 therefore some uncertainty in the shape of the prophylactic profile but if the rapid drop in protection is a 411 real finding, it has implications for the selection of partially resistant parasites to these partner drugs, with 412 lumefantrine potentially having a relatively short window of selection compared to amodiaquine.(76) 413

414 We also did not consider temporal changes in the EIR during the trial. However, these would affect both 415 trial arms equally and could therefore not reverse the relative order of duration of protection between the 416 drugs in one site. Variation between studies may occur due to other factors such as nutritional status, 417 dosage, the genetics of patients or variations in the accuracy of PCR in distinguishing reinfections from 418 recrudescence. For example, PCR accuracy depends on the number of molecular markers used, and in high 419 transmission areas multiple-clone infections can reduce accuracy $(77,78)$. While none of the trials 420 distributed insecticide-treated nets as part of the study, trial areas probably varied in levels of vector control, 421 which is indirectly taken into account in our analysis since we use estimates of transmission intensity based 
medRxiv preprint doi: https://doi.org/10.1101/19002741; this version posted July 20, 2019. The copyright holder for this preprint (which was not certified by peer review) is the author/funder, who has granted medRxiv a license to display the preprint in perpetuity.

It is made available under a CC-BY 4.0 International license.

422 on the Malaria Atlas Project, who use data on prevalence trends and include vector control in their model.

423 In the randomized design of the studies, it is unlikely that one treatment arm would have had better vector

424 control than another, and therefore the comparison of the drugs would not be affected, although the overall

425 reinfection rate for the area could have been different from expected if the effect of vector control was not

426 well reflected in the MAP data and model.

428 In summary, both AL and AS-AQ provide post-treatment prophylaxis which is important for reducing

429 reinfection rates in individuals in higher transmission settings, and may impact on the incidence of malaria

430 in the whole population when these regimens are used widely as first-line treatment. AS-AQ provides

431 longer protection than AL when most infections are by wild-type parasites, while AL provides longer

432 protection than AS-AQ in areas with higher prevalence of the pfmdr1 86Y and pfcrt 76T mutations.

433 Countries may wish to consider the prevalence of these mutations when deciding the first line treatment. In

434 future, it will be important to determine the role of other molecular markers in altering the post-treatment

435 protection provided by ACT partner drugs, such as increased copy number of $p f m d r l$, which is increasing in 436 prevalence in some parts of Africa.(63) 
438 Materials and Methods

439 Data

440 WWARN invited investigators to contribute individual-level patient data for this meta-analysis (79) if their

441 studies fulfilled the following criteria: randomized controlled trials of uncomplicated P. falciparum malaria;

442 AS-AQ and AL being compared; follow-up to at least day 28, with at least one follow-up visit at day 14 and 443 another before day 28; 100 or more participants per study site or more than 28 days follow-up; polymerase

444 chain reaction (PCR)-adjusted efficacy available; at least 95\% PCR-adjusted treatment efficacy in both 445 study arms; PCR-unadjusted cure rates of $<95 \%$ in at least one trial arm by day 28 (to indicate sufficient 446 number of reinfections to inform analysis on post-treatment prophylaxis); standard dose regimens of AL 447 and AS-AQ (we included studies regardless whether AS-AQ was given as a fixed-dose combination or not); 448 and known dosage taken for each patient. Individual patient data from eligible studies were shared, collated 449 and standardized using previously described methodology (80).

451 For the present analyses, we used data on PCR-confirmed reinfections as well as the proportion of patients 452 who were not reinfected during follow up, to estimate the duration of chemoprophylaxis. Time of 453 reinfection is included in the analysis so that different follow up times between studies are accounted for 454 (see also below). Patients who experienced PCR-confirmed recrudescence were excluded. In two studies (in 455 Tororo, Uganda \& Sikasso, Mali, see Table 1) the patients were followed up longitudinally across several 456 episodes, and consequently treated multiple times within short intervals. We only used the first treatment 457 episode and follow-up data collected before the next episode from these studies in order to avoid confounding of our results by residual drug levels from a previous treatment.

460 For each trial, we sought surveys of the prevalence of pfmdr1 86Y, pfmdr1 1246Y and pfcrt 76T mutations 461 in the same country, within $300 \mathrm{~km}$ of the trial site and within 1 year of the trial start or end year (see also 462 Results). For sites with many matching molecular marker surveys, we applied a stricter distance criterion of $463100 \mathrm{~km}$ of the trial site. When more than one matching survey was found, we took a weighted average of the 464 mutant prevalence. We did not include molecular marker studies on post-treatment samples.

466 One included study did not have available data on the individual ages of participants, but provided body 467 weight (55), and another study recorded age but not body weight (49). We imputed the missing values in 468 order to be able to include these studies. To impute missing age, we randomly sampled ages of participants 
medRxiv preprint doi: https://doi.org/10.1101/19002741; this version posted July 20, 2019. The copyright holder for this preprint (which was not certified by peer review) is the author/funder, who has granted medRxiv a license to display the preprint in perpetuity.

469 of the same gender from all other studies who had bodyweights within $0.5 \mathrm{~kg}$ of the observed participants'

470 weights; to impute missing body weight we sampled weights of individuals of the same gender within 0.5

471 years of age for those under 25, and within 5 years for those over 25 years of age.

472

473 Prior information on the force of infection

474 The time to reinfection is determined both by the duration of protection conferred by the drug and the force 475 of infection (FOI) (the number of blood-stage infections acquired per person per year). More specifically, 476 the time span between the end of the protected period and reinfection follows an exponential distribution 477 with mean $1 / \varphi$, assuming a time-constant force of infection $\varphi$. We used predictions of the FOI as prior 478 values in our model, based on prevalence of infection in 2-10 year olds ( $\left.\mathrm{PR}_{2-10}\right)$ estimated by the Malaria 479 Atlas Project (MAP) $(26,27)$. When the trial took place over several years, we averaged slide-prevalence 480 over this time. These $\mathrm{PR}_{2-10}$ values were transformed into predictions of the entomological inoculation rate 481 (EIR) using the relationship between these two variables obtained from our existing mathematical model of 482 malaria transmission (66), allowing calculation of location-specific prior values for $\varphi$ as explained below.

484 Hidden Semi-Markov Models: The transition of an individual from a drug-protected state to a non-protected 485 state, where they are at risk of reinfection after chemoprophylaxis, is not observed. We observe only 486 whether the patient has become reinfected, after a certain time has passed since treatment. This sequence of 487 events can be interpreted as realization of a stochastic process belonging to the class of Hidden Semi488 Markov Models (HSMMs), which we used to estimate the duration of protection provided by treatment. 489 More specifically, we modeled the time to reinfection $R_{i}$ in host $i$ as

$R_{i}=P_{d i}+I_{i}+\delta$

493 where $P_{d i}$ is the duration of chemoprophylaxis of drug $d$ in host $i, I_{i}$ is the time until reinfection occurs in 494 host $i$ once at risk, and $\delta$ represents the time required for a blood-stage infection to become patent after 495 hepatocyte rupture (assumed 3.5 days (81)). $P$ and $I$ were parameterized as random variables as follows:

499 Where the drug-specific scale parameter $\lambda$ and shape parameter $r$ are to be estimated, and 
medRxiv preprint doi: https://doi.org/10.1101/19002741; this version posted July 20, 2019. The copyright holder for this preprint (which was not certified by peer review) is the author/funder, who has granted medRxiv a license to display the preprint in perpetuity.

with $\varphi_{i}$ being the force of infection to which individual $i$ was exposed during the trial follow-up. Individual504 specific EIR values $\varepsilon_{i}$ were determined, taking into account that young children are bitten less often due to their smaller body size, according to the formula

$\varepsilon_{i}=\varepsilon_{a d u l t}\left(1-\rho \exp \left(-a_{i} / a_{0}\right)\right)$

where $\varepsilon_{a d u l t}$ is the estimated site-specific EIR experienced by fully grown individuals, $a$ is age and parameters $a_{0}=2920$ days and $\rho=0.85$ control the shape of the relationship (82). Pre-erythrocytic immunity, i.e. an immune response that reduces the proportion of infectious bites resulting in successful blood stage

512 infections was computed for each individual according to their age, prior exposure and local EIR, using the 513 same mathematical model referenced above (66). For sensitivity analysis, we also tried assuming additional 514 age-independent variation in exposure to mosquito bites, with the distribution of relative biting rates across 515 people following a log-normal distribution. We used informative priors on the lognormal distribution of 516 bites of mean $=1$ and variance $=1.76$ as previously estimated (66).

518 A number of HSMM variants were fitted via MCMC (Markov-Chain Monte Carlo), using the JAGS ("Just 519 Another Gibbs Sampler") software for Bayesian inference in conjunction with the "rjags" package using R 520 statistical software (83). The likelihood calculation took into account the interval- and right-censoring of 521 observations in the data. EIR values $\varepsilon$ adult for each site were estimated simultaneously with the other parameters, with moderately informative gamma priors with median as predicted by MAP (27) (Table 1) and a shape parameter of 1.56. Using this prior information on EIR was essential, otherwise a slow reinfection rate could be explained equally well by either a low EIR or a long drug prophylactic time. After examining the posterior distributions of several candidate models, we included heterogeneity among trial sites in the mean duration of chemoprophylaxis, which was modeled as a gamma-distributed random effect.

527 A weakly informative, empirical-Bayes gamma prior was used for the shape parameter $r$, with

528 hyperparameters (parameters of the prior distribution) determined using a fit of the HSMM with non-

529 informative priors. This improved MCMC convergence. Non-informative gamma priors were chosen for all 530 remaining estimated parameters. We ran the MCMC procedure for 1.25 million iterations, retaining 100,000 
medRxiv preprint doi: https://doi.org/10.1101/19002741; this version posted July 20, 2019. The copyright holder for this preprint (which was not certified by peer review) is the author/funder, who has granted medRxiv a license to display the preprint in perpetuity.

531 samples of the posterior after discarding 4000 adaptation steps, 4000 burn-in steps and thinning.

533 Accelerated failure time models: In order to identify which factors influence the time until a reinfection is 534 detected, we used accelerated failure time models, as implemented in the "survival" package in R (84). We 535 explored lognormal and log-logistic distributions of time to reinfection, which allow the hazard of 536 reinfection to vary over time, and selected lognormal which produced lowest Akaike Information Criterion 537 (AIC). Several covariates were compared with respect to their ability to predict time to reinfection. Since 538 EIR is such a critical predictor of the time to reinfection, we adjusted for this variable in all models, initially 539 in bivariate models with each other covariate, using the log posterior mean EIR estimates from the HSMM 540 analysis for each site. When analyzing age as a covariate, we explored polynomial relationships with 541 reinfection time. The small proportion of individuals in the analysis over 20 years of age (294/3840 with 542 available age data) were grouped together, since model convergence problems were created by lack of data 543 at older ages and because age-dependent exposure to mosquito bites (related to body surface area)(65), as 544 well as development of immunity (66), tends to plateau by 20 years of age. Otherwise, linear relationships 545 were assumed for continuous variables. We tested for interactions between AL or AS-AQ treatment, 546 prevalence of the $p f m d r 186 \mathrm{Y}$ mutant versus N86 wild type parasites and $p f c r t 76 \mathrm{~T}$ mutant versus K76 wild 547 type parasites, since there is evidence of differential effects of each drug on these parasite genotypes $(9,11)$. 548 We tested for an effect of different formulations of AS-AQ, i.e. fixed dose combination (from Sanofi), 549 blister pack or loose dose (see also Table 1 for dose information). For AL, all included studies used the 550 same fixed dose combination from Novartis. We calculated weight-for-age $\mathrm{Z}$ scores for patients under 5 551 years old according to the WHO age and gender specific reference values, using the WHO Anthro software 552 in $\mathrm{R}$ (85). Individuals were classified as underweight if they had a Z score of less than -2 . We investigated 553 being underweight in the children under five years because this was a factor associated with recrudescence 554 after AL in a previous analysis.(10) We calculated mg per $\mathrm{kg}$ dose of lumefantrine or amodiaquine for each 555 patient according to their dose and weight. Goodness of fit of the models was assessed by Akaike's 556 Information Criterion (AIC). We used stepwise regression, with both forward selection and backward 557 elimination to ensure all covariates of interest were identified. The best-fitting model was identified using 558 AIC and covariates significantly improving the prediction (LR-test) were kept.

560 Epidemiological Simulations: An existing mathematical model of Plasmodium falciparum epidemiology 561 (66) was used to assess the impact of first-line antimalarial treatment on malaria transmission outcomes. 
medRxiv preprint doi: https://doi.org/10.1101/19002741; this version posted July 20, 2019. The copyright holder for this preprint (which was not certified by peer review) is the author/funder, who has granted medRxiv a license to display the preprint in perpetuity. It is made available under a CC-BY 4.0 International license.

562 The probability of a mosquito becoming infected when feeding on individuals treated with AL relative to 563 untreated individuals was assumed to be 0.051 (66). It is uncertain whether there is any difference in human 564 infectiousness after treatment with AL versus AS-AQ. We therefore ran the simulations twice, assuming 565 firstly that patients are equally infectious after treatment with either ACT, and secondly assuming that 566 patients treated with AS-AQ are twice as infectious, in approximate accordance with the ratio of areas under 567 curves of post-treatment gametocyte prevalence in Schramm et al (47) which is consistent with a meta568 analysis showing reduced gametocytemia after treatment with AL compared with AS-AQ (67). The model 569 was first run to equilibrium in the absence of interventions, then we simulated first line treatment with AS$570 \mathrm{AQ}$ or AL, assuming that $80 \%$ of clinical episodes are treated with an antimalarial, that both drugs are $95 \%$ 571 efficacious at clearing parasites and that the switch is instantaneous and complete. Prior to introducing ACT, 572 we assume SP was in use, also at $80 \%$ coverage but only $60 \%$ efficacy. We simulated a population of 573600,000 individuals to smooth stochastic variation. We adjusted mosquito densities to represent low, 574 medium and high transmission areas (pre-intervention slide prevalence in $2-10$ year olds $=5 \%, 15 \%$ and $57550 \%$, respectively in the non-seasonal settings). In the simulations with seasonal variation, we adjusted 576 mosquito densities to achieve the same annual EIR as in each respective low, medium or high transmission 577 non seasonal setting.

579 Ethical approval

580 All data included in this analysis were obtained after ethical approvals from the countries of origin. Use of 581 existing data which are fully anonymized and which researchers cannot trace back to identifiable 582 individuals does not require the review of the Ethics Committee under the guidelines of the Oxford Central 583 University Research Ethics Committee.

585 Software and data availability

586 Analysis code in $\mathrm{R}$ and the transmission model executable file are fully available online at 587 https://github.com/lucyokell/duration_protection_AL_ASAQ, as are the data underlying the figures:

588 (Zenodo data repository DOI 10.5281/zenodo.3339215). The source code for the transmission model in $589 \mathrm{C}++$ will be made available on Github prior to any full manuscript submission. The original individual level 590 clinical trial data is available upon request from WWARN (https://www.wwarn.org/accessing-data). 591 Requests must be approved by the data contributor and the WWARN Malaria Data Access Committee 
medRxiv preprint doi: https://doi.org/10.1101/19002741; this version posted July 20, 2019. The copyright holder for this preprint (which was not certified by peer review) is the author/funder, who has granted medRxiv a license to display the preprint in perpetuity.

593 Author contributions

594 Conceptualization (MT Bretscher, LC Okell, AC Ghani, PJ Guerin); Methodology (MT Bretscher, LC

595 Okell, J Griffin, K Stepniewska, P Dahal, AC Ghani); Software, Validation \& Formal analysis (MT

596 Bretscher, LC Okell, J Griffin); Resources \& Data curation (Q Bassat, E Baudin, H Bukirwa, U

597 D'Alessandro, P Dahal, AA Djimde, G Dorsey, E Espié, B Fofana, R González, PJ Guerin, E Juma, C

598 Karema, E Lasry, B Lell, N Lima, C Menéndez, G Mombo-Ngoma, C Moreira, F Nikiema, JB Ouédraogo,

599 SG Staedke, K Stepniewska, H Tinto, I Valea, A Yeka); Writing - original draft preparation \& Visualization

600 (MT Bretscher, LC Okell); Writing - review \& editing (All).

601

602 Acknowledgements

603 We thank H Bukirwa, C Nabasumba, B Schramm and Sanofi for providing data from the original clinical 604 trials. We thank Christian Nsanzabana at the Swiss Tropical and Public Health Institute for technical 605 support, and Francois Bompart, Valerie Lameyre and Muriel Mannechez at Sanofi for providing comments 606 on the manuscript. This work was supported by Medicines for Malaria Venture. LCO also acknowledges 607 funding from a UK Royal Society Dorothy Hodgkin fellowship, the Bill \& Melinda Gates Foundation, a 608 joint fellowship from the UK Medical Research Council (MRC) and the UK Department for International 609 Development (DFID) under the MRC/DFID Concordat agreement, and joint Centre funding from the UK 610 Medical Research Council and DFID (MR/R015600/1). ISGlobal is a member of the CERCA Programme, 611 Generalitat de Catalunya (http://cerca.cat/en/suma/). CISM is supported by the Government of Mozambique 612 and the Spanish Agency for International Development (AECID).

615 Competing interests

616 LCO declares prior grant funding from the World Health Organization and Medicines for Malaria Venture 617 in addition to the funding already declared in the acknowledgements. The other authors declare no 618 competing interests. 
medRxiv preprint doi: https://doi.org/10.1101/19002741; this version posted July 20, 2019. The copyright holder for this preprint (which was not certified by peer review) is the author/funder, who has granted medRxiv a license to display the preprint in perpetuity.

Supplementary Figures and Tables

Table S1. Risk factors for reinfection: multivariable analysis with $p f c r t 76 \mathrm{~T}$.

Data from AS-AQ and AL trial arms were analyzed separately using accelerated failure-time analysis. Regression coefficients are the ratio of time to reinfection, such that a coefficient $>1$ indicates a longer time to reinfection. Covariates significantly associated with reinfection time after adjusting for EIR (Table 3, main text) were included in the final model. The prevalence of $p f m d r 186 \mathrm{Y}$ also had a significant effect in a multivariable model with the same covariates (Table 3, main text) but could not be included in the same model with pfcrt 76T due to strong correlation between the two variables. Models assume a log-normal time to reinfection and random site effects.

\begin{tabular}{|c|c|c|c|c|}
\hline \multirow[b]{2}{*}{ Covariate (unit) } & \multicolumn{2}{|l|}{$\begin{array}{l}\text { AL multivariable model }(\mathrm{N}=1724) \text { : } \\
\text { EIR, age, dose, pfcrt1 } 76 \mathrm{~T}\end{array}$} & \multicolumn{2}{|c|}{$\begin{array}{l}\text { AS-AQ multivariable model } \\
(\mathrm{N}=1998) \\
\text { EIR, age, pfcrt1 76T }\end{array}$} \\
\hline & $\begin{array}{l}\text { Coefficient [ratio of reinfection } \\
\text { times] }(95 \% \mathrm{CI})\end{array}$ & $\mathrm{P}$ value & $\begin{array}{l}\text { Coefficient [ratio of } \\
\text { reinfection times] }(95 \% \\
\text { CI) }\end{array}$ & $P$ value \\
\hline $\log _{\mathrm{e}} \mathrm{EIR}$ & $0.80(0.74,0.87)$ & $<0.001$ & $0.81(0.74,0.87)$ & $<0.001$ \\
\hline $\begin{array}{l}\text { age (years, }>20 \\
\text { grouped together) } \\
\text { age } \\
(\text { age })^{2} \\
(\text { age })^{3}\end{array}$ & $\begin{array}{l}1.02(0.94,1.11) \\
1.00(0.98,1.02) \\
1.0001(0.9993,1.0010)\end{array}$ & $<0.001$ & $\begin{array}{l}0.94(0.886,1.00) \\
1.01(1.00,1.02) \\
0.9997(0.9992,1.0001)\end{array}$ & $<0.001$ \\
\hline $\begin{array}{l}\text { Lumefantrine } \\
\text { dose (per } 10 \mathrm{mg} \\
\text { per kg increase) } \\
\text { (in AL arms only) }\end{array}$ & $1.03(1.01,1.05)$ & 0.002 & - & \\
\hline $\begin{array}{l}\text { pfmdr } 76 \mathrm{~T} \\
\text { prevalence (per } \\
10 \% \text { increase) }\end{array}$ & $1.04(1.01,1.07)$ & 0.005 & $0.98(0.95,1.01)$ & 0.162 \\
\hline
\end{tabular}


medRxiv preprint doi: https://doi.org/10.1101/19002741; this version posted July 20, 2019. The copyright holder for this preprint (which was not certified by peer review) is the author/funder, who has granted medRxiv a license to display the preprint in perpetuity.

Figure S1. The duration of post-treatment prophylaxis at different trial locations in order of increasing estimated EIR.

Posterior estimates of the duration of protection provided by AL or AS-AQ are shown. The study sites are shown in order of increasing transmission intensity left to right according to posterior EIR estimates.

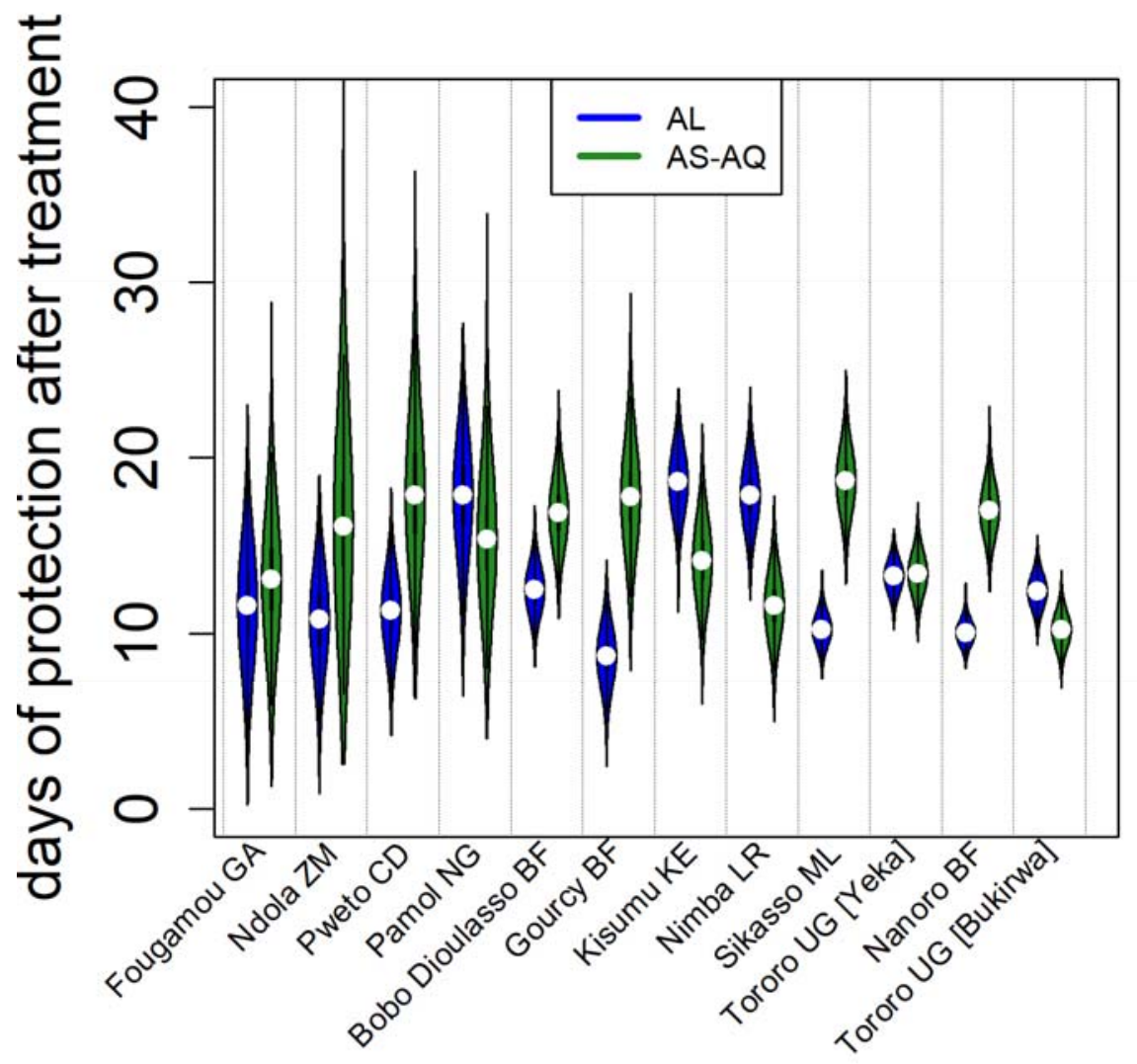


medRxiv preprint doi: https://doi.org/10.1101/19002741; this version posted July 20, 2019. The copyright holder for this preprint (which was not certified by peer review) is the author/funder, who has granted medRxiv a license to display the preprint in perpetuity. It is made available under a CC-BY 4.0 International license.

Figure S2. Correlation between $p f c r t 76 \mathrm{~T}$ prevalence and $p f m d r 86 \mathrm{Y}$ prevalence, in the surveys matched to the trial sites according to year and geographic distance. When more than one molecular marker survey was matched to a trial site, a weighted average prevalence was taken. In some cases, these two molecular markers were assessed in the same matched survey(s), but in other cases matches from different surveys were found.

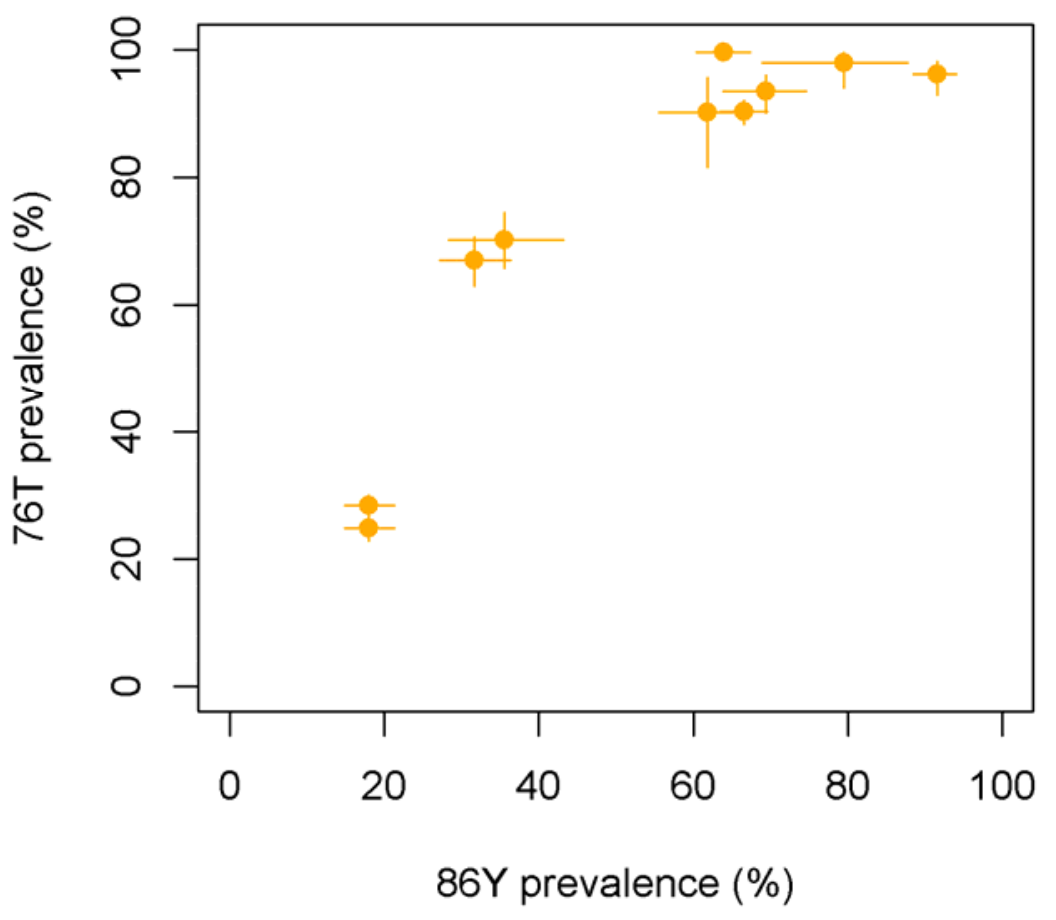


medRxiv preprint doi: https://doi.org/10.1101/19002741; this version posted July 20, 2019. The copyright holder for this preprint (which was not certified by peer review) is the author/funder, who has granted medRxiv a license to display the preprint in perpetuity.

It is made available under a CC-BY 4.0 International license.

Figure S3 Simulated annual seasonal variation in EIR assumed in the analysis of potential impact of AL and AS-AQ on population level transmission (Figure 5, main text). The EIR shown is for the simulated seasonal medium transmission setting (slide prevalence $=15 \%$ ), but the relative EIR variation across the year was the same in the seasonal low and high simulated transmission settings.

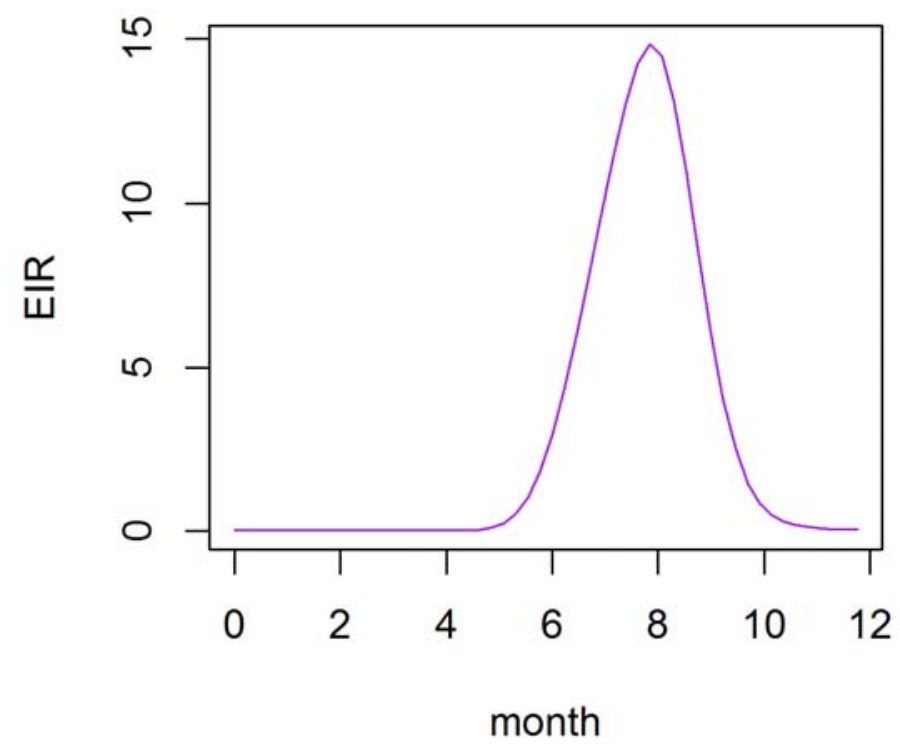


medRxiv preprint doi: https://doi.org/10.1101/19002741; this version posted July 20, 2019. The copyright holder for this preprint (which was not certified by peer review) is the author/funder, who has granted medRxiv a license to display the preprint in perpetuity.

Figure S4. As Figure 5 in the main text, except panels B,C,E and F show impact on clinical incidence in the whole population (rather than 0-5 year old children only).
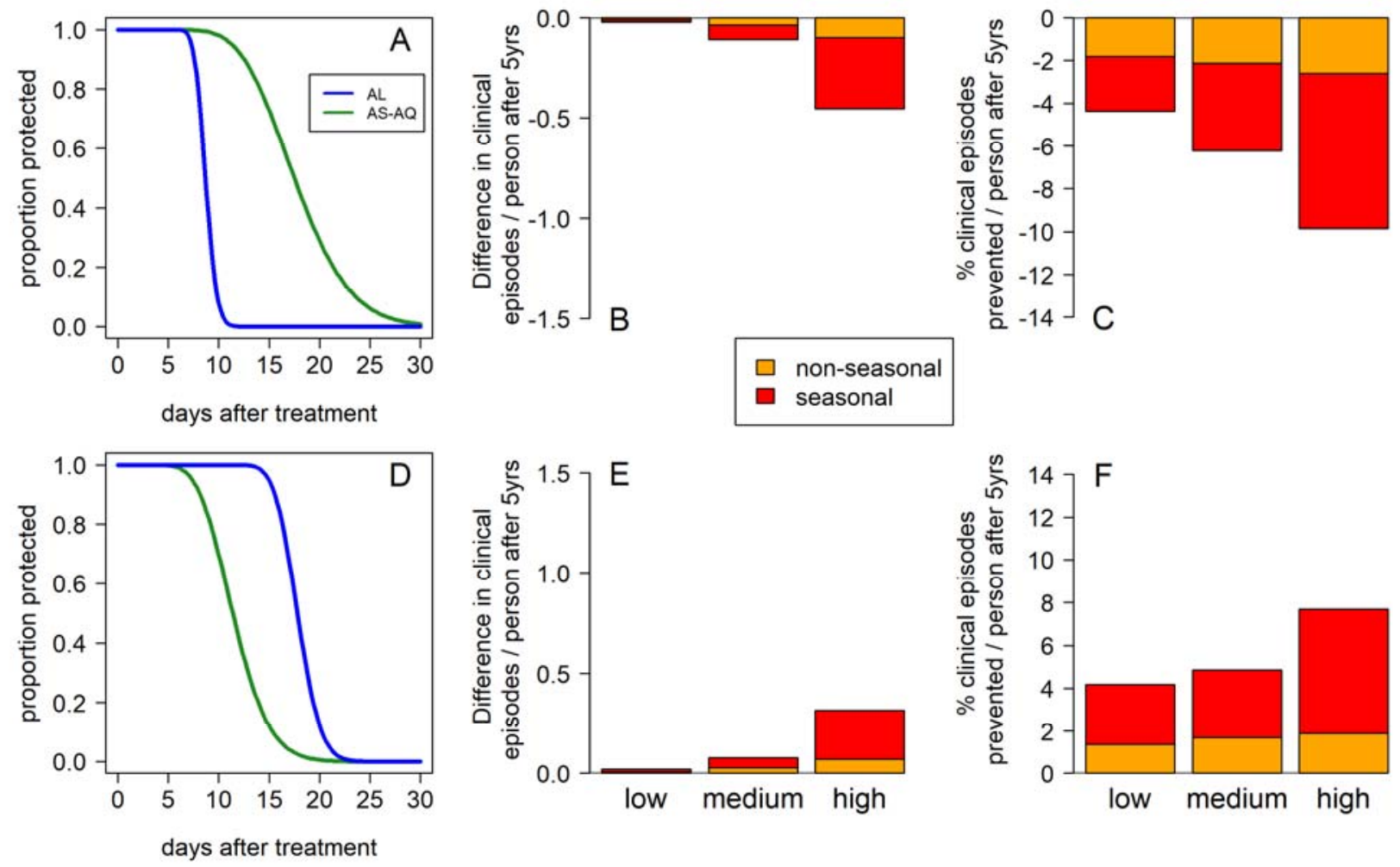
medRxiv preprint doi: https://doi.org/10.1101/19002741; this version posted July 20, 2019. The copyright holder for this preprint (which was not certified by peer review) is the author/funder, who has granted medRxiv a license to display the preprint in perpetuity. It is made available under a CC-BY 4.0 International license.

\section{References}

1. World Health Organization. WHO Guidelines for the treatment of malaria. 3rd edition. 2015.

2. World Health Organization. Q\&A on artemisinin resistance.

https://www.who.int/malaria/media/artemisinin_resistance qa/en/ Accessed November 2018. 2018.

3. malERA. A research agenda for malaria eradication: drugs. PLoS Med. 2011;8(1):e1000402.

4. Okell LC, Cairns M, Griffin JT, Ferguson NM, Tarning J, Jagoe G, et al. Contrasting benefits of different artemisinin combination therapies as first-line malaria treatments using model-based costeffectiveness analysis. Nat Commun. 2014;5:5606.

5. Okell LC, Drakeley CJ, Bousema T, Whitty CJ, Ghani AC. Modelling the impact of artemisinin combination therapy and long-acting treatments on malaria transmission intensity. PLoS Med. 2008;5(11):e226; discussion e.

6. Cairns M, Ghani A, Okell L, Gosling R, Carneiro I, Anto F, et al. Modelling the protective efficacy of alternative delivery schedules for intermittent preventive treatment of malaria in infants and children. PLoS One. 2011;6(4):e18947.

7. World Health Organization. World Malaria Report 2018. Accessed at https://www.who.int/malaria/publications/world-malaria-report-2018/en/ 05/01/19. 2018.

8. Tun KM, Imwong M, Lwin KM, Win AA, Hlaing TM, Hlaing T, et al. Spread of artemisininresistant Plasmodium falciparum in Myanmar: a cross-sectional survey of the K13 molecular marker. Lancet Infect Dis. 2015;15(4):415-21.

9. Venkatesan M, Gadalla NB, Stepniewska K, Dahal P, Nsanzabana C, Moriera C, et al. Polymorphisms in Plasmodium falciparum chloroquine resistance transporter and multidrug resistance 1 genes: parasite risk factors that affect treatment outcomes for P. falciparum malaria after artemetherlumefantrine and artesunate-amodiaquine. Am J Trop Med Hyg Erratum https:/wwwwwarnorg/sites/default/files/attachments/documents/erratum-full-paper-polymorphismspfcrt-pfmdr1-ajtmh-november-2019pdf. 2014 Erratum 2019;91(4):833-43.

10. Worldwide Antimalarial Resistance Network (WWARN) AL Dose Impact Study Group. The effect of dose on the antimalarial efficacy of artemether-lumefantrine: a systematic review and pooled analysis of individual patient data. Lancet Infect Dis. 2015.

11. $\quad$ Erratum. Am J Trop Med Hyg. 2019;100(3):766.

12. Worldwide Antimalarial Resistance Network (WWARN) AS-AQ Study Group. The effect of dosing strategies on the therapeutic efficacy of artesunate-amodiaquine for uncomplicated malaria: a meta-analysis of individual patient data. BMC Med. 2015.

13. Ashley EA, Stepniewska K, Lindegardh N, McGready R, Annerberg A, Hutagalung R, et al. Pharmacokinetic study of artemether-lumefantrine given once daily for the treatment of uncomplicated multidrug-resistant falciparum malaria. Trop Med Int Health. 2007;12(2):201-8.

14. Tarning J, Kloprogge F, Dhorda M, Jullien V, Nosten F, White NJ, et al. Pharmacokinetic properties of artemether, dihydroartemisinin, lumefantrine, and quinine in pregnant women with uncomplicated plasmodium falciparum malaria in Uganda. Antimicrob Agents Chemother. 2013;57(10):5096-103.

15. Djimde A, Lefevre G. Understanding the pharmacokinetics of Coartem. Malar J. 2009;8 Suppl $1:$ S4.

16. Kloprogge F, McGready R, Hanpithakpong W, Blessborn D, Day NP, White NJ, et al. Lumefantrine and Desbutyl-Lumefantrine Population Pharmacokinetic-Pharmacodynamic Relationships in Pregnant Women with Uncomplicated Plasmodium falciparum Malaria on the Thailand-Myanmar Border. Antimicrob Agents Chemother. 2015;59(10):6375-84.

17. Tarning J, Chotsiri P, Jullien V, Rijken MJ, Bergstrand M, Cammas M, et al. Population 
pharmacokinetic and pharmacodynamic modeling of amodiaquine and desethylamodiaquine in women with Plasmodium vivax malaria during and after pregnancy. Antimicrob Agents Chemother. 2012;56(11):5764-73.

18. Adjei GO, Kristensen K, Goka BQ, Hoegberg LC, Alifrangis M, Rodrigues OP, et al. Effect of concomitant artesunate administration and cytochrome $\mathrm{P} 4502 \mathrm{C} 8$ polymorphisms on the pharmacokinetics of amodiaquine in Ghanaian children with uncomplicated malaria. Antimicrob Agents Chemother. 2008;52(12):4400-6.

19. Hietala SF, Bhattarai A, Msellem M, Roshammar D, Ali AS, Stromberg J, et al. Population pharmacokinetics of amodiaquine and desethylamodiaquine in pediatric patients with uncomplicated falciparum malaria. J Pharmacokinet Phar. 2007;34(5):669-86.

20. Hombhanje FW, Hwaihwanje I, Tsukahara T, Saruwatari J, Nakagawa M, Osawa H, et al. The disposition of oral amodiaquine in Papua New Guinean children with falciparum malaria. Brit J Clin Pharmaco. 2005;59(3):298-301.

21. Mwesigwa J, Parikh S, McGee B, German P, Drysdale T, Kalyango JN, et al. Pharmacokinetics of artemether-lumefantrine and artesunate-amodiaquine in children in Kampala, Uganda. Antimicrob Agents Chemother. 2010;54(1):52-9.

22. Stepniewska K, Taylor W, Sirima SB, Ouedraogo EB, Ouedraogo A, Gansane A, et al. Population pharmacokinetics of artesunate and amodiaquine in African children. Malar J. 2009;8:200. 23. 4ABC Study Group. A head-to-head comparison of four artemisinin-based combinations for treating uncomplicated malaria in African children: a randomized trial. PLoS Med.

2011;8(11):e1001119.

24. Gosling RD, Cairns ME, Chico RM, Chandramohan D. Intermittent preventive treatment against malaria: an update. Expert Rev Anti Infect Ther. 2010;8(5):589-606.

25. Worldwide antimalarial resistance network (WWARN). http://www.wwarn.org/.

26. Malaria Atlas Project. Accessed at http://www.map.ox.ac.uk/data/ 07/07/2016. 2015.

27. Bhatt S, Weiss DJ, Cameron E, Bisanzio D, Mappin B, Dalrymple U, et al. The effect of malaria control on Plasmodium falciparum in Africa between 2000 and 2015. Nature. 2015;526(7572):207-11.

28. Mawili-Mboumba DP, Ndong Ngomo JM, Maboko F, Guiyedi V, Mourou Mbina JR, Kombila $\mathrm{M}$, et al. Pfcrt 76T and pfmdr1 86Y allele frequency in Plasmodium falciparum isolates and use of selfmedication in a rural area of Gabon. Trans R Soc Trop Med Hyg. 2014;108(11):729-34.

29. Frank M, Lehners N, Mayengue PI, Gabor J, Dal-Bianco M, Kombila DU, et al. A thirteen-year analysis of Plasmodium falciparum populations reveals high conservation of the mutant pfcrt haplotype despite the withdrawal of chloroquine from national treatment guidelines in Gabon. Malar J.

2011;10:304.

30. Espie E, Lima A, Atua B, Dhorda M, Flevaud L, Sompwe EM, et al. Efficacy of fixed-dose combination artesunate-amodiaquine versus artemether-lumefantrine for uncomplicated childhood Plasmodium falciparum malaria in Democratic Republic of Congo: a randomized non-inferiority trial. Malar J. 2012;11:174.

31. Happi CT, Gbotosho GO, Folarin OA, Sowunmi A, Hudson T, O'Neil M, et al. Selection of Plasmodium falciparum multidrug resistance gene 1 alleles in asexual stages and gametocytes by artemether-lumefantrine in Nigerian children with uncomplicated falciparum malaria. Antimicrob Agents Chemother. 2009;53(3):888-95.

32. Folarin OA, Bustamante C, Gbotosho GO, Sowunmi A, Zalis MG, Oduola AM, et al. In vitro amodiaquine resistance and its association with mutations in pfert and pfmdr1 genes of Plasmodium falciparum isolates from Nigeria. Acta Trop. 2011;120(3):224-30.

33. Oladipo OO, Wellington OA, Sutherland CJ. Persistence of chloroquine-resistant haplotypes of 
Plasmodium falciparum in children with uncomplicated Malaria in Lagos, Nigeria, four years after change of chloroquine as first-line antimalarial medicine. Diagn Pathol. 2015;10:41.

34. Ojurongbe O, Oyedeji SI, Oyibo WA, Fagbenro-Beyioku AF, Kun JF. Molecular surveillance of drug-resistant Plasmodium falciparum in two distinct geographical areas of Nigeria. Wien Klin Wochenschr. 2010;122(23-24):681-5.

35. Nikiema F, Zongo I, Some F, Ouedraogo J. Evolution of therapeutic efficacies of artemisininbased combination therapies (ASAQ and AL) for treatment of uncomplicated falciparum malaria in Burkina Faso during five years of adoption as first-line treatments (unpublished). 2010.

36. Some AF, Zongo I, Compaore YD, Sakande S, Nosten F, Ouedraogo JB, et al. Selection of drug resistance-mediating Plasmodium falciparum genetic polymorphisms by seasonal malaria chemoprevention in Burkina Faso. Antimicrob Agents Chemother. 2014;58(7):3660-5.

37. Sondo P, Derra K, Diallo Nakanabo S, Tarnagda Z, Kazienga A, Zampa O, et al. ArtesunateAmodiaquine and Artemether-Lumefantrine Therapies and Selection of Pfcrt and Pfmdr1 Alleles in Nanoro, Burkina Faso. PLoS One. 2016;11(3):e0151565.

38. Some AF, Sorgho H, Zongo I, Bazie T, Nikiema F, Sawadogo A, et al. Polymorphisms in K13, pfcrt, pfmdr1, pfdhfr, and pfdhps in parasites isolated from symptomatic malaria patients in Burkina Faso. Parasite. 2016;23:60.

39. Sondo P, Derra K, Tarnagda Z, Nakanabo SD, Zampa O, Kazienga A, et al. Dynamic of plasmodium falciparum chloroquine resistance transporter gene Pfcrt K76T mutation five years after withdrawal of chloroquine in Burkina Faso. Pan Afr Med J. 2015;21:101.

40. Zongo I, Milligan P, Compaore YD, Some AF, Greenwood B, Tarning J, et al. Randomized Noninferiority Trial of Dihydroartemisinin-Piperaquine Compared with Sulfadoxine-Pyrimethamine plus Amodiaquine for Seasonal Malaria Chemoprevention in Burkina Faso. Antimicrob Agents Chemother. 2015;59(8):4387-96.

41. Juma EA. Efficacy of co-administered amodiaquine plus artesunate and artemether/lumefantrine for the treatment of uncomplicated falciparum malaria in children less than five years in different epidemiological settings in Kenya. Unpublished. 2004.

42. Holmgren G, Bjorkman A, Gil JP. Amodiaquine resistance is not related to rare findings of pfmdr1 gene amplifications in Kenya. Trop Med Int Health. 2006;11(12):1808-12.

43. Zhong D, Afrane Y, Githeko A, Cui L, Menge DM, Yan G. Molecular epidemiology of drugresistant malaria in western Kenya highlands. BMC Infect Dis. 2008;8:105.

44. Vardo-Zalik AM, Zhou G, Zhong D, Afrane YA, Githeko AK, Yan G. Alterations in Plasmodium falciparum genetic structure two years after increased malaria control efforts in western Kenya. Am J Trop Med Hyg. 2013;88(1):29-36.

45. Bonizzoni M, Afrane Y, Baliraine FN, Amenya DA, Githeko AK, Yan G. Genetic structure of Plasmodium falciparum populations between lowland and highland sites and antimalarial drug resistance in Western Kenya. Infect Genet Evol. 2009;9(5):806-12.

46. Spalding MD, Eyase FL, Akala HM, Bedno SA, Prigge ST, Coldren RL, et al. Increased prevalence of the $\mathrm{pfdhfr} / \mathrm{phdhps}$ quintuple mutant and rapid emergence of pfdhps resistance mutations at codons 581 and 613 in Kisumu, Kenya. Malar J. 2010;9:338.

47. Schramm B, Valeh P, Baudin E, Mazinda CS, Smith R, Pinoges L, et al. Efficacy of artesunateamodiaquine and artemether-lumefantrine fixed-dose combinations for the treatment of uncomplicated Plasmodium falciparum malaria among children aged six to 59 months in Nimba County, Liberia: an open-label randomized non-inferiority trial. Malar J. 2013;12:251.

48. Otienoburu SD, Maiga-Ascofare O, Schramm B, Jullien V, Jones JJ, Zolia YM, et al. Selection of Plasmodium falciparum pfcrt and pfmdr1 polymorphisms after treatment with artesunate- 
amodiaquine fixed dose combination or artemether-lumefantrine in Liberia. Malar J. 2016;15:452. 49. Sagara I, Fofana B, Gaudart J, Sidibe B, Togo A, Toure S, et al. Repeated artemisinin-based combination therapies in a malaria hyperendemic area of Mali: efficacy, safety, and public health impact. Am J Trop Med Hyg. 2012;87(1):50-6.

50. Tekete M, Djimde AA, Beavogui AH, Maiga H, Sagara I, Fofana B, et al. Efficacy of chloroquine, amodiaquine and sulphadoxine-pyrimethamine for the treatment of uncomplicated falciparum malaria: revisiting molecular markers in an area of emerging AQ and SP resistance in Mali. Malar J. 2009;8:34.

51. Sagara I, Oduro AR, Mulenga M, Dieng Y, Ogutu B, Tiono AB, et al. Efficacy and safety of a combination of azithromycin and chloroquine for the treatment of uncomplicated Plasmodium falciparum malaria in two multi-country randomised clinical trials in African adults. Malar J. 2014;13:458.

52. Andriantsoanirina V, Menard D, Rabearimanana S, Hubert V, Bouchier C, Tichit M, et al. Association of microsatellite variations of Plasmodium falciparum $\mathrm{Na}+\mathrm{H}+$ exchanger (Pfnhe-1) gene with reduced in vitro susceptibility to quinine: lack of confirmation in clinical isolates from Africa. Am J Trop Med Hyg. 2010;82(5):782-7.

53. Djimde AA, Fofana B, Sagara I, Sidibe B, Toure S, Dembele D, et al. Efficacy, safety, and selection of molecular markers of drug resistance by two ACTs in Mali. Am J Trop Med Hyg. 2008;78(3):455-61.

54. Doumbo S, Ongoiba OA, Doumtabe D, Dara A, Ouologuem TD, Kayentao K, et al. [Prevalence of Plasmodium falciparum, anemia and molecular markers of chloroquine and sulfadoxinepyrimethamine resistance in delivered women in Fana, Mali]. Bull Soc Pathol Exot. 2013;106(3):18892.

55. Yeka A, Lameyre V, Afizi K, Fredrick M, Lukwago R, Kamya MR, et al. Efficacy and safety of fixed-dose artesunate-amodiaquine vs. artemether-lumefantrine for repeated treatment of uncomplicated malaria in Ugandan children. PLoS One. 2014;9(12):e113311.

56. Mbogo GW, Nankoberanyi S, Tukwasibwe S, Baliraine FN, Nsobya SL, Conrad MD, et al. Temporal changes in prevalence of molecular markers mediating antimalarial drug resistance in a high malaria transmission setting in Uganda. Am J Trop Med Hyg. 2014;91(1):54-61.

57. Tumwebaze P, Conrad MD, Walakira A, LeClair N, Byaruhanga O, Nakazibwe C, et al. Impact of antimalarial treatment and chemoprevention on the drug sensitivity of malaria parasites isolated from ugandan children. Antimicrob Agents Chemother. 2015;59(6):3018-30.

58. Tukwasibwe S, Mugenyi L, Mbogo GW, Nankoberanyi S, Maiteki-Sebuguzi C, Joloba ML, et al. Differential prevalence of transporter polymorphisms in symptomatic and asymptomatic falciparum malaria infections in Uganda. J Infect Dis. 2014;210(1):154-7.

59. Some AF, Sere YY, Dokomajilar C, Zongo I, Rouamba N, Greenhouse B, et al. Selection of known Plasmodium falciparum resistance-mediating polymorphisms by artemether-lumefantrine and amodiaquine-sulfadoxine-pyrimethamine but not dihydroartemisinin-piperaquine in Burkina Faso. Antimicrob Agents Chemother. 2010;54(5):1949-54.

60. Bukirwa H, Yeka A, Kamya MR, Talisuna A, Banek K, Bakyaita N, et al. Artemisinin combination therapies for treatment of uncomplicated malaria in Uganda. PLoS Clin Trials. 2006;1(1):e7.

61. Nsobya SL, Dokomajilar C, Joloba M, Dorsey G, Rosenthal PJ. Resistance-mediating Plasmodium falciparum pfcrt and pfmdr1 alleles after treatment with artesunate-amodiaquine in Uganda. Antimicrob Agents Chemother. 2007;51(8):3023-5.

62. Ochong E, Tumwebaze PK, Byaruhanga O, Greenhouse B, Rosenthal PJ. Fitness Consequences 
of Plasmodium falciparum pfmdr1 Polymorphisms Inferred from Ex Vivo Culture of Ugandan Parasites. Antimicrob Agents Chemother. 2013;57(9):4245-51.

63. Worldwide Antimalarial Resistance Network. ACT Partner Drug Molecular Surveyor. http://www.wwarn.org/tracking-resistance/act-partner-drug-molecular-surveyor. Accessed April 2018. 64. Okell LC, Reiter LM, Ebbe LS, Baraka V, Bisanzio D, Watson OJ, et al. Emerging implications of policies on malaria treatment: genetic changes in the Pfmdr-1 gene affecting susceptibility to artemether-lumefantrine and artesunate-amodiaquine in Africa. BMJ Glob Health. 2018;3(5):e000999.

65. Port GR, Boreham PFL, Bryan JH. The relationship of host size to feeding by mosquitoes of the Anopheles gambiae Giles complex (Diptera: Culicidae). Bull Entomological Res. 1980;70(133-144). 66. Griffin JT, Ferguson NM, Ghani AC. Estimates of the changing age-burden of Plasmodium falciparum malaria disease in sub-Saharan Africa. Nat Commun. 2014;5:3136.

67. WWARN Gametocyte Study Group. Gametocyte carriage in uncomplicated Plasmodium falciparum malaria following treatment with artemisinin combination therapy: a systematic review and meta-analysis of individual patient data. BMC Med. 2016;14:79.

68. Slater HC, Okell LC, Ghani AC. Mathematical Modelling to Guide Drug Development for Malaria Elimination. Trends Parasitol. 2017;33(3):175-84.

69. Falk N, Maire N, Sama W, Owusu-Agyei S, Smith T, Beck HP, et al. Comparison of PCR-rflp and genescan-based genotyping for analyzing infection dynamics of Plasmodium falciparum. Am J Trop Med Hyg. 2006;74(6):944-50.

70. Yeka A, Kigozi R, Conrad MD, Lugemwa M, Okui P, Katureebe C, et al. Artesunate/Amodiaquine Versus Artemether/Lumefantrine for the Treatment of Uncomplicated Malaria in Uganda: A Randomized Trial. J Infect Dis. 2016;213(7):1134-42.

71. The Global Fund. Pooled Procurement Mechanism Reference Pricing: Antimalarial medicines. https://www.theglobalfund.org/en/sourcing-management/health-products/antimalarial-medicines/ Accessed 20/12/18. 2018.

72. Pfeil J, Borrmann S, Tozan Y. Dihydroartemisinin-piperaquine vs. artemether-lumefantrine for first-line treatment of uncomplicated malaria in African children: a cost-effectiveness analysis. PLoS One. 2014;9(4):e95681.

73. Coldiron ME, Von Seidlein L, Grais RF. Seasonal malaria chemoprevention: successes and missed opportunities. Malar J. 2017;16(1):481.

74. World Health Organization. WHO Policy Recommendation: Seasonal Malaria Chemoprevention (SMC) for Plasmodium falciparum malaria control in highly seasonal transmission areas of the Sahel sub-region in Africa. Accessed at https://wwwwhoint/malaria/publications/atoz/who_smc policy recommendation/en/ 14/03/19. 2012. 75. http://www.tropmedres.ac/trac-ii-2 Accessed March 2018.

76. Kay K, Hastings IM. Measuring windows of selection for anti-malarial drug treatments. Malar J. 2015;14:292.

77. Jaki T, Parry A, Winter K, Hastings I. Analysing malaria drug trials on a per-individual or perclone basis: a comparison of methods. Stat Med. 2013;32(17):3020-38.

78. Martensson A, Ngasala B, Ursing J, Isabel Veiga M, Wiklund L, Membi C, et al. Influence of consecutive-day blood sampling on polymerase chain reaction-adjusted parasitological cure rates in an antimalarial-drug trial conducted in Tanzania. J Infect Dis. 2007;195(4):597-601.

79. http://www.wwarn.org/working-together/study-groups/aq-post-treatment-prophylaxis-studygroup.

80. WWARN. Clinical Module: Data Management and Statistical Analysis Plan. Version 1.2. WorldWide Antimalarial Resistance Network, Oxford, 2012. 
medRxiv preprint doi: https://doi.org/10.1101/19002741; this version posted July 20, 2019. The copyright holder for this preprint (which was not certified by peer review) is the author/funder, who has granted medRxiv a license to display the preprint in perpetuity. It is made available under a CC-BY 4.0 International license.

81. Hermsen CC, Telgt DS, Linders EH, van de Locht LA, Eling WM, Mensink EJ, et al. Detection of Plasmodium falciparum malaria parasites in vivo by real-time quantitative PCR. Mol Biochem Parasitol. 2001;118(2):247-51.

82. Griffin JT, Hollingsworth TD, Okell LC, Churcher TS, White M, Hinsley W, et al. Reducing Plasmodium falciparum malaria transmission in Africa: a model-based evaluation of intervention strategies. PLoS Med. 2010;7(8):e1000324.

83. Plummer M. rjags: Bayesian graphical models using MCMC. R package version 3-10. http://CRAN.R-project.org/package=rjags. 2013.

84. Therneau T. A Package for Survival Analysis in S. version 2.38, http://CRAN.Rproject.org/package=survival. 2015.

85. World Health Organization. WHO anthro software, igrowup R package https://www.who.int/childgrowth/software/en/ Accessed 14/12/18. 2011. 